

\section{DISCLAIMER}

This report was prepared as an account of work sponsored by an agency of the United States Government. Neither the United States Government nor any agency Thereof, nor any of their employees, makes any warranty, express or implied, or assumes any legal liability or responsibility for the accuracy, completeness, or usefulness of any information, apparatus, product, or process disclosed, or represents that its use would not infringe privately owned rights. Reference herein to any specific commercial product, process, or service by trade name, trademark, manufacturer, or otherwise does not necessarily constitute or imply its endorsement, recommendation, or favoring by the United States Government or any agency thereof. The views and opinions of authors expressed herein do not necessarily state or reflect those of the United States Government or any agency thereof. 


\section{DISCLAIMER}

Portions of this document may be illegible in electronic image products. Images are produced from the best available original document. 
BNL 50614

(Energy Conservation-Buildings

and Community Systems - TID-4500)

\title{
RESIDENTIAL SPACE HEATING AND COOLING \\ IN NEW ENGLAND 1972-2000
}

\author{
RICHARD DAIFUKU
}

December 1976

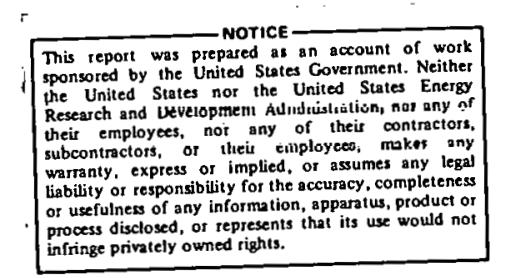

\section{ECONOMIC ANALYSIS DIVISION \\ NATIONAL CENTER FOR ANALYSIS OF ENERGY SYSTEMS}

BROOKHAVEN NATIONAL LABORATORY

UPTON, NEW YORK II973 
NOTICE

This report was prepared as an account of work sponsored by the United States Government. Neither the United States nor the United States Energy Research and Development Administration, nor any of their employees, nor any of their contractors,

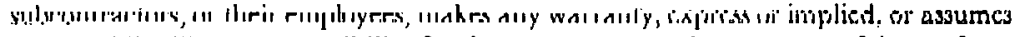
any legal liability or responsibility for the accuracy, completeness or usefulness of any information, apparatus, product or process disclosed, or represents that its use would not infringe privately owned rights.

Printed in the United States of America Available from

National Technical Information Service

U.S. Department of Commerce

5285 Port Royal Road

Springfield, VA 22161

Price: Printed Copy \$5.50; Microfiche $\$ 3.00$
February 1977
615 copies 
The object of this report on Residential space Heating and ai.r conditioning in New England is to develop a model for predicting energy demand from this sector and for assessing energy conservation policy options. To this end, the housing stock is disaggregated by type and insulation levels. This allows the definition of targets for potential insulation retrofit program, and as a result of the dynamic nature of the model, older, poorly insulated housing is allowed to be replaced over time by new units of higher thermal integrity.

Under a set of assumptions, including those pertaining to system efficiencies, electric heat pump penetration, and likely energy conservation decisions, energy use in this sector demonstrates a slight decrease at the end use level between the years 1972 and 2000. This document has provided the methodology for a computerized simulation model of residential space heating and cooling being developed for the New England Energy Management Information System (NEMIS) at the Massachusetts Institute of Technology with a data base specific to each of the six New England States. 
I am indebted to Brookhaven National Laboratory and particularly William Marcuse, Head of the Division of Economic Analysis, for providing me with the opportunity to write this report; to sheldon Licht, a consultant architect at BNL, for his technical advice; to Richard Furman and Janet Williams of the Center for Energy Policy, the former for gathering some of the necessary reference material, and the latter for her editorial assistance; and to Barbara Jones for her help in preparing the final document. 
I. Introduction............................ vi

II. Prototypical housing units.................... I

III. Construction and thermal integrity of prototypical building structures........................ 2 A. Insulation levels for $S F D, S F A$ and MFLR......... 2 B. Insulation levels for MFHR and mobile homes...... 7 IV. New England's space heating and cooling energy requirements........................... 10

V. Conclusion............................... 15

\section{APPENDICES}

1. Design parameters for prototypical building

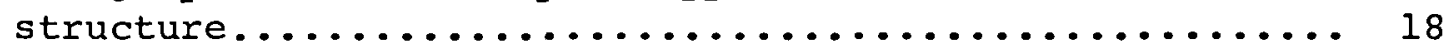

2. Coefficients of transmission for the structural components of prototypical buildings............. 25

3. Methodology for calculating heating and cooling requirements of building structures............ 32

4. Heating requirements of prototypical building

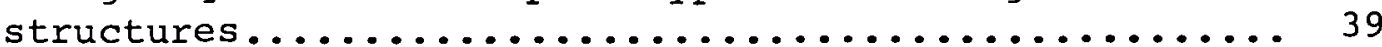

5. Cooling requirements of prototypical building structures.............................. 67

6. New England's inventory of residential housing........ 86

7. Fuel mix tables.............................. 90

8. Saturation levels of other residential energy uses..... 102

I. Existing ceiling insulation, Northeast............ 4

II. Insulation levels for prototypical SFD, SFA

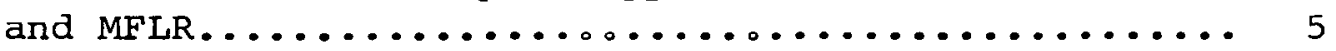

III. Minimum property standards, U-factor at 4501-

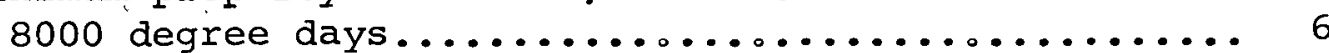

IV. Presence of insulation, $1973 \ldots \ldots \ldots \ldots \ldots \ldots \ldots \ldots \ldots \ldots . \ldots$

V. Insulation levels for prototypical MFHR............ 9

VI. Living unit space heating and cooling requirements.... 11

VII. Housing age distribution..................... 12

VIII. New England's space heating and cooling requirements $1972-2000$ 


\section{INTRODUCTION}

Space heating and air conditioning account for $59.6 \%$ of the residential energy use nationally (Dole, 1975), and over 65\% in New England (Lee, 1975). At a time of rising energy costs and energy scarcity, it becomes imperative to attempt to reduce consumption in this highly visible end use sector. This can be done by the retrofitting of existing housing with insulation and im:proving the thermal integrity of future housing. The ASHRAE: 90-75 standard (Arthur D. Little, 1975), proposed for voluntary adoption by individual building regulatory authorities, is an example of the latter approach.

The purpose of this report is to develop a model of the total fuel demand for space heating and cooling of Niew Ingland's housing stock over the period 1972-2000. This modcl relies on an exhaustive literature search of the construction characteristics of the present housing stock. Data on the insulation levels of existing building structures are not only presented on a regional level for an "average" structure, but are also sufficiently disaggregated to potentially allow for the determination of the energy conserved through an insulation retrofit program. In this model the characteristics of new construction are assumed to depend in the near future on the existing Minimum Property standards, and in the longer term, on the likely strengthening of these standards and the adoption of state standards. 
In calculating heating and cooling reguirements for a region, it is essential to consider representative building categories. For the purposes of this model, housing is subdivided into the following categories:

-SFD: single family detached

-SFA: single family attached (1-4 units, attached)

-MFLR: multifamily low-rise (5-19 units)

-MFHR: multifamily high rise (20 units and over)

-Mobile homes

The model incorporates an increase in the surface area of dwellings over time for two housing types, SFA and SFD; all others are assumed invariant. Tyson (1975) derived the figures used here from information provided by the National Association of Home Builders.

The U.S. Bureau of Census (1975) reports an average of $70 \%$ of new, privately owned one-family homes in the Northeast to be frame construction. This proportion is presumably higher in New England. Thus, in agreement with the assumptions of Arthur D. Little (1974), all SFD, SFA and MFLR structures are considered to have frame construction and similar levels of insulation. Two other important characteristics are associated with these three building categories: a two story height and unheated basements. The average number of stories in New England for one-family homes is 1.76 (U.S. Department of Housing and Urban Development, 1973), and this will be approximated here by a two story height. Further, 90.7 percent of the buildings were found to have basements (U.S. Bureau of Census, 1970).

The MFHR is the only masonry structure considered in the model. This building type is assumed to have a heated basement. A detailed listing of all building structure characteristics may be found in Appendix 1 . 


\section{CONSTRUCTION AND THERMAL INTEGRITY \\ OF PROTOTYPICAL BUILDING STRUCTURES}

Based on published characteristics of exterior surface, ceiling and floor construction (Arthur D. Little, 1974 and 1975; ASHRAE, 1972), it is possible to determine the overall coefficients of transmission or U-values* for a variety of surfaces. The total resistance to heat flow through a flat ceiling, floor or wall is equal numerically to the sum of the resistances in series:

$$
\begin{aligned}
\mathrm{R}_{\mathrm{T}}=\sum_{1}^{\mathrm{n}} \mathrm{R}_{i} & \\
\text { where: } \quad \mathrm{R}_{i} & =\text { individual resistance of a component } \\
\mathrm{R}_{\mathrm{T}} & =\text { total resistance }
\end{aligned}
$$

The resistance to heat flow is different in summer and in winter, significantly so in the vertical direction. This difference is partly the result of lower exterior wind speeds. Wind velocities of $15 \mathrm{mph}$ are assumed for winter conditions and $7.5 \mathrm{mph}$ for summer conditions. However, the difference is also a function of the direction of. heat flow in air spaces. More resistance is offered to flow in the downward direction than in the upward direction. A detailed tabulation of the structural components used in calculating the coefficients of transmission is presented in Appendix 2.

$$
\text { A. INSULATION LEVELS FOR SFD。 SFA AND MFLR }
$$

Data on insulation levels are very sparse, be it nationally or regionally. Whatever information is available suffers from a small sample size or is collected from respondents unrepresentative of the population at large. For example, the ceiling insulation levels reported by homeowners in Danbury. Connecticut, for a pilot project in energy conservation appear very high when compared to the available body of data (Federal Energy Administration, 1974). A recent

*The U-value is the overall coefficient of heat transmission, i.e., the time rate of heat flow expressed in Btu per (hour) $x$ (square foot) $\mathrm{x}$ (Fahrenheit degree temperature difference between air on the outside of a wäl, floor, roof or ceiling). 'l'he term is also applied to the usual combination of materials, and also single materials, such as window glass. The R-value is simply the reciprocal of $U$ (ASHRAE, 1972). Fiberglass batts most commonly have $R$ values of $5,7,11$ and 19 with corresponding thicknesses of $1 \frac{1}{2}, 2 \frac{1}{4}, 3 \frac{1}{2}$ and 6 inches. 
survey of 4,200 homeowners, conducted by Owens Corning Fiberglass was used as the basis , for the determination of ceiling insulation levels (see Table I). This sample size is larger by more than one ordar of magnitude than the preceding, although the possibility remains that the thermal integrity of homeowners " dwellings differs from the remainder of housing stock. The insulation characteristics chosen for SFD, SFA and MFLR are shown in TableII and are consistent with known practice.

It is important to note that federal standards exist setting minimum levels of insulation, the minimum property standards (MPS) (see Table III). Although these standards only have a direct effect upon approximately 35 percent of all new construction in the United states, they have an indirect effect on virtually all construction. Few residential builders will fail to meet Federal Housing Administration (FHA) standards and thereby miss the opportunity to qualify for FHA financing; conversely few builders will exceed these standards because there is little economic advantage gained (New England Energy Policy Staff, 1973). All structures built after 1972 and all electrically heated buildings are assumed to meet or exceed present FHA insulation standards. The proportion of storm windows and doors, weatherstripping and caulking is assumed to be $100 \%$ for all new and electrically heated construction. A level of $75 \%$ storm windows and doors is representative of all other construction over time (Federal Energy Administration, 1974; Donovan and Fischer, 1976), as is a figure of $50 \%$ for weatherstripping and caulking (Donovan and Fischer, 1976).

Electrically heated homes tend to have higher insulation levels than fossil fuel heated homes. This reflects the need to offset the higher cost of electrical energy. Over $80 \%$ of the electric heating units present in New England in 1972 were installed after 1965 (Center for Energy Policy, 1976). Thus only post-1965 housing units are considered candidates for electrical heating.

Present wall construction uses 2 by 4 inch studs, thus allowing the placcment of a maximum of 3.5 inches of fiberglass with a resistance (R) of eleven. Pre-1940 homes are broken down into two categories: insulated and uninsulated. Prior to 1940, walls were most often insulated with "granulated mineral wool." Granulated wool is loose wool that has been granulated and rolled into pellets of about half an inch in diameter. It was used principally for insulating buildings already constructed since it could be blown into spaces between studs by an air hose. In 1942, granulated wool was the most popular form of insulation and accounted for $48.2 \%$ of all sales by weight (U.S. Department of Commerce, 1947). However, blown-in insulation is known to settle over time and has a lower R-value than fiberglass batts $(2.2$ per inch versus 3.7 per 
Table I

Existing ceiling Insulation, Northeast ${ }^{1}$

Thickness of insulation (inches)

None

2.25

3

$3-4$

4

5

6
Percentage of homes

14.5

10.6

21.2

6.4

26.1

10.0

11.2

${ }^{\perp}$ Based on survey of 4,200 homeowners by owens Curning Fiberglass 
Table II

Insulation levels for prototypical SFD, SFA and MFLR

\begin{tabular}{|c|c|c|c|c|c|}
\hline Category & Walls & $\begin{array}{c}\text { Ceiling under } \\
\text { Attic } \\
\end{array}$ & $\begin{array}{r}\text { Ground } \\
\text { Floor } \\
\end{array}$ & $\begin{array}{l}\% \text { storm } \\
\text { Windows }\end{array}$ & $\begin{array}{c}\% \text { Storm } \\
\text { Doors }\end{array}$ \\
\hline Post - 1972 & & & & & \\
\hline electric & $\mathrm{R}-11$ & $R-24$ & Foil + R-5 & 100 & 100 \\
\hline fossil & $\mathrm{R}-11$ & $\mathrm{R}-19$ & Foil + R-5 & 100 & 100 \\
\hline $1965-1972$ & & & & & \\
\hline electric & $R-I I$ & $\mathrm{R}-19$ & Foil + R-5 & 200 & 100 \\
\hline fossil & $R-11$ & $R=19$ & Foil & 75 & 75 \\
\hline $1940-1965$ & $\mathrm{R}-7$ & $\mathrm{R}-11$ & $\mathrm{R}-0$ & 75 & 75 \\
\hline Pre-- 1940 & & & & & \\
\hline with insulation & $90 \% R-8$ & $\mathrm{R}-7$ & $\mathrm{R}-0$ & 75 & 75 \\
\hline without insulation & $\begin{array}{l}10 \% \mathrm{R}-0 \\
\mathrm{R}-0\end{array}$ & R-O & $\mathrm{R}-0$ & 75 & 75 \\
\hline
\end{tabular}


Table III

\title{
Minimum property standards
}

\author{
U-factor at $4501-8000$ \\ degree däys 1
}

Building

Element

MPS 1 and 2

MPS

family

multi-family

Net wall:

-frame

-masonry

Glazing :
.08

.10

.65
.07

.12

where more than $25 \%$ of exposed exterior wall is glass, at least $\frac{1}{4}$ of all glass surface shall be insulating glass or storm sash
Doors

Roof-Ceiling:

- frame

-masonry

Flat roof deck
.65

$.05^{2}$

.05

.05

.05

.09

.1 ?

Floor over unheated space:

-wood and steel frame .08

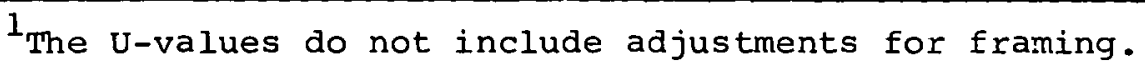

2 This corresponds to an insulation level of R-19-For post1972 electrically heated homes, the requirement for 8001 or more degree-day areas was used, $i . e ., u=0.04$ or $R-24$.

Sources: Cohen and White (1975)

U.S. Department of Housing and Urban Development (1974) 
inch). Petersen (1974) estimates a minimum of $10 \%$ settling. Thus pre-1940 homes with insulated walls are assumed to have insulation levels equivalent to $90 \% \mathrm{R}-8$ and $10 \% \mathrm{R}-0$. The proportion of uninsulated buildings is presented in Table IV.

\section{B. INSULATION LEVELS FOR MFHR AND MOBILE HOMES}

The construction and thermal characteristics of the pre-1972 fossil-fuel heated MFHR in this model are similar to those proposed by Arthur D. Little (1974)。The electrically heated buildings and all post-1972 MFHR are assumed to meet the MPS for multifamily dwellings (Table III). This requires insulation with ureaformaldehyde, as the space available between the furring is not sufficiently deep to allow the placement of fiberglass. Insulation levels for the prototypical MFHR are given in Table $V$.

All existing mobile homes are assumed to be similarly constructed. This is sufficiently accurate for our purposes since mobile homes have a relatively short life-time and thus a high turnover rate. 
Table IV

$$
\frac{\text { Presence of insulation, } 1973^{1}}{\text { (percent of households) }}
$$

Single Family Homes $^{2} \quad$ Multi-Family Homes $^{3}$

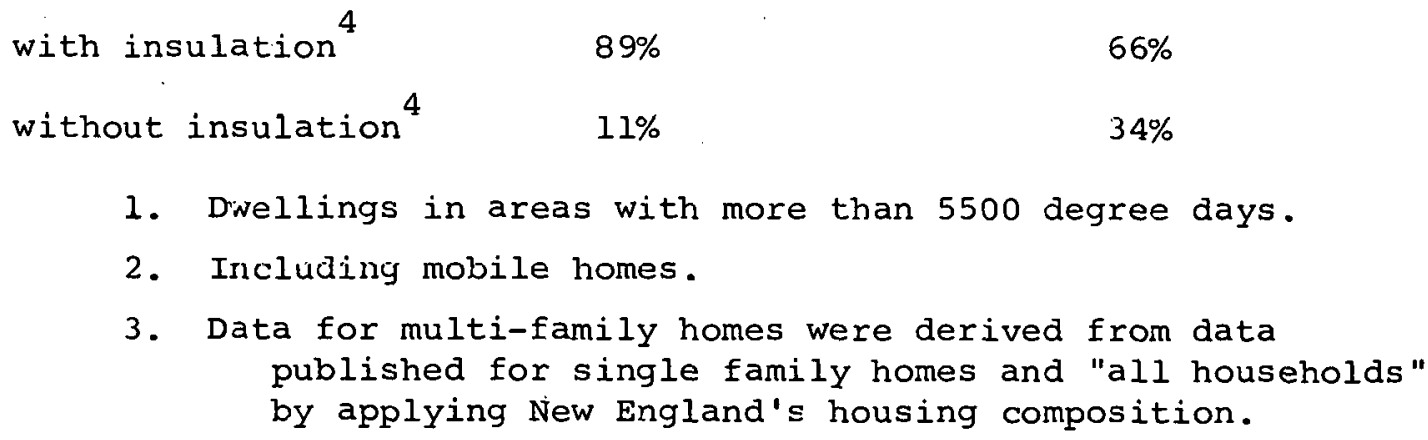

4. The respondents unaware of the level of insulation in their homes were apportioned to those who did in the two categories "with insulation" and "without insulation".

Source: Washington Center for Metropolitan Studies' Lifestyles and Finergy Surveys-Munted in: Newman, L.K. and Layp $\nu$. The American energy consumer. Ballinger publishing company, Canbrialye, Mass.. 1975, p. 38. 
Table V

Insulation levels for prototypical MFHR

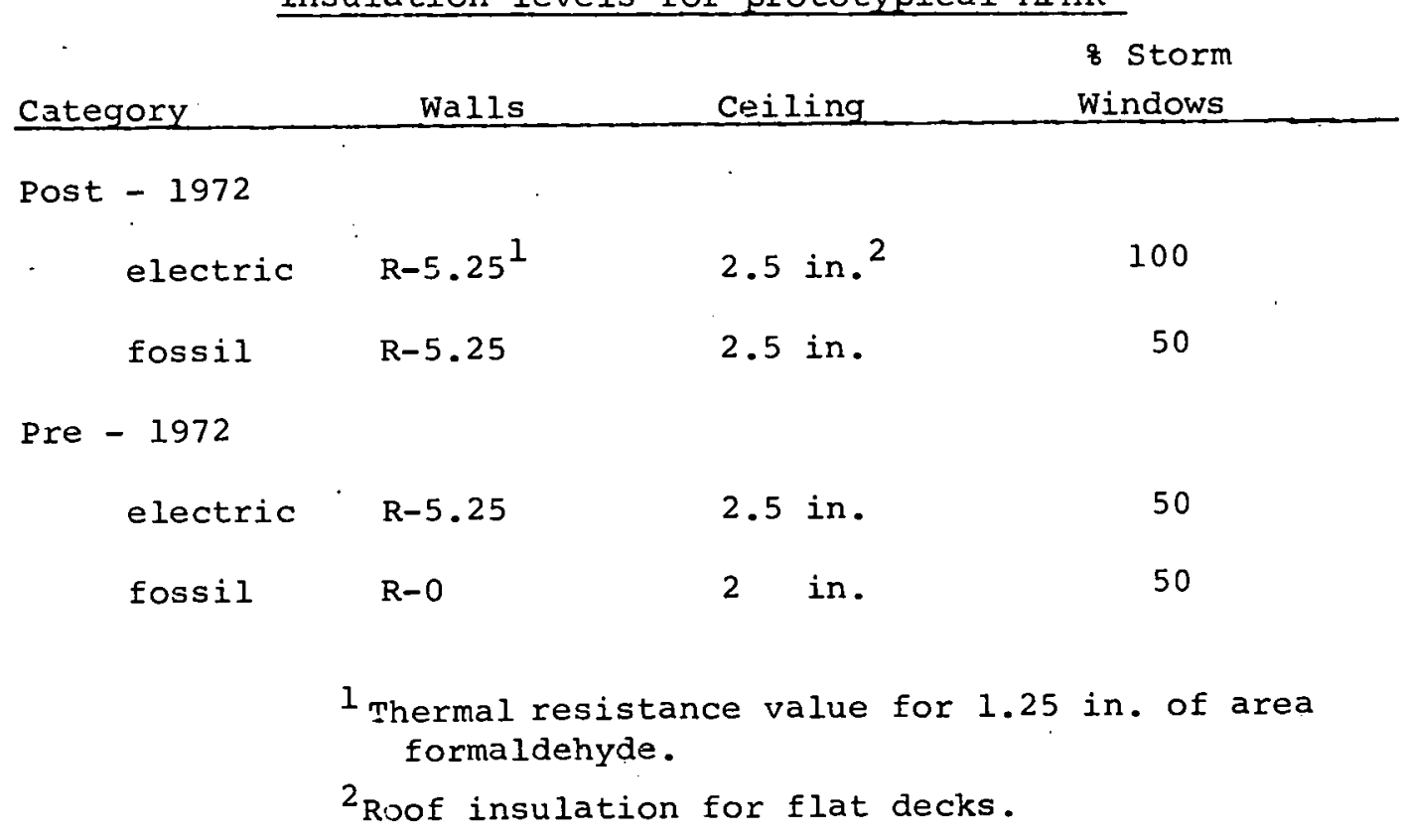




\section{NEW ENGLAND'S SPACE HEATING AND COOLING ENERGY REQUIREMENTS}

Once construction characteristics and insulation levels are known, it is straightforward to calculate heating and cooling requirements for each type of building structure. Appendix 3 explains the methodology used for the calculations, while Appendices 4 and 5 tabulate the results for heating and cooling。 respectively. When the energy requirements of each structure are known, a division by the number of units comprising each structure type yields the heating and cooling requirements for each living unit, as presented in Table VI. The energy requirements are seen to decrease with increased insulation levels or aggregatıon of units willıil a structure. It should be noted that the comparatively large heating requirements of uninsulated buildings renders them the best targets for retrofitting of insulation or removal from the housing stock.

With the unit heating and cooling requirements calculated, it becomes possible to determine the requirements for the region based on the residential inventory of housing. New England's residential inventory was determined from the housing projections developed by Lee (1976). In order to acquire a breakdown of housing by type over time, data on new construction was used (Marcin。 1972 and 1975), under the assumption that houses built after 1939 were not removed from the inventory prior to 1972. The housing distribution obtained (see Appendix 6), if averaged over ail housing types approximates very closely New England's present housing mix (see Tabile VTT.).

Based on the housing distribution, the average energy reqiitrements of a living unit type, the unit basic demand, for a given $y e a r$ and fuel can be calculated. This is done in the fuel mix tables (see Appendix 7). When projecting energy demand to the year 2000, all new homes built after 1985 are assumed to consume 5\% less energy than in 1972 because of improved design, and $2 \%$ less because of more efficient use of the structure, and existing structures to consume 3\% less because of improved efficiency and $2 \%$ less for use.

The following assumptions were made to arrive at the heating and cooling system efficiencies presented in the fuel mix tables:

\section{Heating Utilization Efficiencies}

Fuel Type

Gas

Oil

Electricity (resistance)

Heating Utilization Efficiencies

Existing Construction New Construction

0.60

0.50

0.70

1.00

Source:
Adapted from Arthur
0.60

1.00 
Table VI

Living Unit Space Heating and Cooling Requirements

Living Unit

SFD

1972-1985 electric fossil

1965-1972 elecțic fossil

1940-1965

Pre-1940 insulated uninsulated

SFA

1972-1985 electric fossil

1965-1972 electric fossil

1940-1965

Pre-1940 insulated uninsulated

MFLR
Heating Reguirement $\left(10^{6}\right.$ BTU)

61.6

68.5

63.0

76.5

84.5

88.8

145.7

37.3

42.3

38.3

48.0

61.4

66.2

103.3

27.0

30.9

27.9

35.3

47.1

49,9

81.1

33.0

31.2

29.2

44.9

52.6

56.1
Cooling Requirement $\left(10^{6}\right.$ BTU)

10.33

10.40

8.53

8.37

9.59

6.35

6.40

6.20

6.33

8.10

4.88

4.93

5.16

5.37

6.70

5.04

5.39

5.64 
Table VII

Housing Age Distribution

1. From the U.S. Bureau of Census (1972).

Age group

1965-70

1940-65

Pre -40

2. Derived from Marcin (1972 and 1975).

Age group

1965-72

1940-65

Pre -1940
Percentage of housing Units in each age group

10.1
33.5
56.4

Percentage of housing Units in each age group 31.7

56.3 
Al1 pre-1972 construction is considered "existing." An average utilization efficiency for the housing stock is calculated for 1985 and 2000 for each structure type. The period 1985 to 2000 witnesses the introduction of heat pumps. As a measure of the efficiency of heat pumps, the seasonal performance factor (S.P.F.) is used rather than the coefficient of performance (C.O.P.). The $C_{0} O_{\circ} P_{0}$ decreases as the outside temperature drops and thus heat pump are. less efficient in colder climates. The S.P.F。 for a heat-pump in the Boston area is 1.71 and this figure is applied to the New England region (Chan, 1974).

2. Cooling Coefficients of Performance

Air conditioning

\begin{tabular}{llr} 
& \multicolumn{2}{c}{ Air conditioning } \\
Year & \multicolumn{2}{c}{ Coefficients of performance } \\
\hline 1972 & Room & $\frac{\text { Central }}{1.99}$ \\
1985 & 2.82 & 2.44 \\
2000 & 2.75 & 3.01
\end{tabular}

Source: Derived from Arthur D. Little, 1974.

The efficiencies of air conditioning units are assumed to increase over time, given a reasonably active continuation of industry and government labeling.

The energy requirements calculated for cooling in appendix 5 relate only to central systems. Determining unit demands for room air conditioners requires different assumptions. In 1972 a about $18 \%$ of all homes in New England were cooled by room air conditioners. Each home averaged 1.44 units, assuming 2.5 units per home with two or more units (U.S. Bureau of Census, 1972). This average is expected to increase to 1.66 units in 1985 and then remain stationary as central air conditioning and heat pumps become more prevalent. Dole (1975) has calculated that the average room unit has a capacity of $11.750 \mathrm{BTU} / \mathrm{hr}$. Based on an $85 \%$ use factor, the unit demand of room air conditioners can be derived from the following equation:

$$
\begin{array}{rl}
\mathrm{E}_{\mathrm{u}}=.85 \times 1.750 \times \mathrm{Nu} \times \mathrm{CH} \times \mathrm{SA} \div \mathrm{SA} & \mathrm{av} \\
\text { where: } \mathrm{Nu}= & \text { number of units } \\
\mathrm{CH}= & \text { number of cooling hours per year } \\
\mathrm{SA} & =\text { average surface area of a living unit } \\
& \text { type for a given year } \\
\mathrm{SA} & =\text { average surface area of all living } \\
\mathrm{av} & \text { units for a given year }
\end{array}
$$

This equation assumes that the number of air-conditioner units is a function of the surface area of the living unit. The values of $\mathrm{SA}$ av are as follows:

$$
\begin{array}{llll}
\text { year: } & 1972 & 1985 & 2000 \\
\mathrm{SA}_{\mathrm{av}}{ }^{2} \text { feet }^{2}: & 1290 & 1381 & 1469
\end{array}
$$


The final output that can be obtained from the fuel mix table is presented in Table VIII. This is a summation of energy requirements for heating and cooling over all housing types. The total fuel demand for space heating shows a small downward trend due to the increase in the thermal integrity of the housing stock and increased utilization efficiencies. However this decrease would actually be an increase if generation efficiencies for electricity were included in the energy demand calculations.

Table VIII

New England's Space Heating and Cooling Requirements $1972-2000$ (1012 BTU)

1972

$\underline{1985}$

2000

Space heating:

-methane:

111.1

104.9

83.7

-distillate:

454.6

440.4

389.8

-electricity:

7.7

25.9

56.2

Total fuel demand

for space heating:

573.4

571.2

529.7

Cooling :

$$
\text { -electricity : }
$$

Total for space

heating and cooling: 575.8

575.4

540.0 


\section{CONCLUSION}

In this model of residential space heating and cooling in New England, the housing stock is divided into five building structure categories. These categories are further subdivided based on available data on the thermal integrity of the structures. Energy requirements within a given structure category vary widely depending on the levels of insulation. The uninsulated buildings in New England's housing stock have energy requirements that are more than double those of recent well insulated buildings. Fortunately, from an energy consumption standpoint, many of the uninsulated buildings will be removed from the housing stock over the time interval considered. An effective retrofitting program should be directed at improving the thermal integrity of the remainder and of pre-1965 homes generally. Economic analyses are necessary to determine the optimum levels of insulation for the region based on present and projected fuel prices, as well as the expected lifetime of the structures.

Knowledge of the residential housing inventory disaggregated by type of unit renders feasible the calculation of the total fuel demand for the region. This fuel demand is not only dependent on the mix of building structures and their thermal integrities, but also on the estimates of the fuel fractions and fuel utilization efficiencies.

With likely improvements in the thermal integrity of the housing stock and in fuel utilization efficiencies over the period 1972-2000, the overall energy requirements for space heating and cooling in New England show a downward trend at the end use level. However, this trend does not take into account the conversion efficiencies of electric power generation plants of the order of 30 to 40 percent. If such efficiencies were included in the model. the total energy consumption would in fact increase.

Although other residential energy uses, e.g.. cooking, water heating and lighting have not been analyzed here, saturation lẹvels for New England have been determined and are presented in Appendix 8 . 


\section{REFERENCES}

1. American Society of Heating, Refrigerating and Air-Conditioning Engineers. ASHRAE handbook of fundamentals. New York, 1972.

2. Anderson, RoW. Residential Energy Consumption...Single Family housing. Hittman Associates Columbia, Maryland, 1973。 (Report No. HUD-HAI-2) .

3. Arthur D. Little。 Inc. Residential and Commercial use Pattern 1970-1990. Cambridge, Massachusetts, 1974.

4. Arthur D. Little, Inc. An Impact Assessment of ASHRAE Standard 90-75, Energy Conservation in New Building Design. Cambridge。 Massachusetts。1975.

5. Center for Energy Yolicy. Space Heating Energy Conservation in New England. Boston, Massachusetts, 1976.

6. Chan, D.C. Residential Energy Consumption and Small-Scale Options of Energy Systems for Space Heating. Mitre Corporation, Bedford, Massachusetts, 1974.

7. Cohen, J.C. and White, P.H. Energy Conservation in Buildings: The New York Metropolitan Region. Environmental Law Institute。 Washington, D.C.。1975.

8. Dole。 S.H. Energy Use and Conservation in the Residential Sector: A Regional Analysis。 Rand, Santa Monica, California, 1975.

9. Donovan。 J.J. and Fischer,W.P. Factors Affecting Residential Heating Energy Consumption. In preparation.

10. Federal Energy Administration. Project Conserve. .A Pilot Project in Homeowner Energy Conservation. Washington, D.C., 1974.

11. Hittman Associates. Residential Energy Consumption...Multifamily Housing. oFinal Report. Columbia, Maryland, 1974.

12. Lee。 J. Energy Supply and Demand in the Northeast United States. Brookhaven National Laboratory, Upton, New York, 1976.

13. - A Ferspective on the Eneryy Fulure of the Northeast United States--Residential and Commercial Energy Demand. Brookhaven National Laboratory, Upton, New York, 1975.

14. Marcin, T.C. Projection of Demand for Housing by Type of Unit and Region. U.S. Department of Agriculture, Forest Service, 1972 .

15. Will Houeing Domand Boom Again? IT.S. Mepart.ment of Agriculture, Forest Service, 1975.

16. New England Energy Policy Staff. Energy in New England 1973 to 2000. Boston, Massachusetts, 1973.

17. Petersen, S.R. Retrofitting Existing Housing for Energy Conservation: An Economic Analysis. National Bureau of Standards Building Science Series 64, U.S. Department of Commerce, Washington, D.C.。 1974.

18. Tyson, M。 Residential Heat Load Calculations for the Northeast. Unpublished manuscript. 
19. U.S. Bureau of Census. 1970 Census of Housing--Housing Characteristics for states, Cities and Counties. Vol. 8 , $21,23,31,41$ and 47 . U.S. Department of Commerce, Washington, D.C., 1972 .

20. Construction Reports--Characteristics of New One-Family Homes: 1974. U.S. Department of Commerce, Washington, D.C., 1975.

21. U.S. Department of Commerce. Insulation Materials for Buildings.

21 Washington, D.C., 1947.

22. U.S. Department of Housing and Urban Development. FHA Homes-Data for States and Selected Areas. Washington, D.C。。 1973 and 1974 a.

23. . Minimum Property Standards for one and Two Family Dwellings. Revision No. 1. Washington, D.C., 1974 b. 
Appendix 1

Design parameters for

Prototypical Building Structures 
Design Parameters Applicable to

all Structures (except- where noted)

1. All windows are assumed to be $3 \times 5$ feet double hung. Therefore the crack length is $(2 \times 5)+(3 \times 3)$ or 19 feet and the frame length is approximated by $(2 \times 5)+(2 \times 3)$ or 16 feet.

2. All doors are assumed to be $3 \times 62 / 3$ feet or 20 feet $^{2}$ and thus have a perimeter of $191 / 3$ feet.

3. All structures having basements, i.e., excluding mobile homes, have the following design parameters:*

- Area of basement windows: $2 \%$ of floor surface area

- Net basement wall above grade $=.25$ (gross basement wall area) - area of basement windows

- Basement wall area beloin grade $=.75$ (gross basement wall area).

4. SFD。SFA and MFLR structures are assumed to have a roof with a $25^{\circ}$ pitch. *From Petersen (1974). 
Design parameters for single-family detached structure *

Pre-1940

Width $\mathrm{x}$ length $\mathrm{x}$ height, feet

Floor-ceiling area, feet $^{2}$

Gross wall, feet ${ }^{2}$

Glazing (\% of floor area)

Glass area, feet $^{2}$

Sash crack length, feet

Frame crack length, feet

Door area, feet ${ }^{2}$

Door crack length, feet

Net wall, feet ${ }^{2}$

Roof arca, fcet ${ }^{2}$

End walls of attic, feet ${ }^{2}$

Area of basement windows, feet ${ }^{2}$

Gross area basement wall a feet ${ }^{2}$

Net wall above grade. feet ${ }^{2}$

Wall below grade, feet ${ }^{2}$

$20 \times 30 \times 18$

1200

1800

12

144

182

154

40

39

1616

$6 \in 2$

93

12

700

163

525 $\underline{1940-65}$

Post-1965

$21 \times 31 \times 1823 \times 35 \times 18$

1302

1610

1872

2088

12

15

156

242

198

307

166

258

40

40

39

39

1676

1806

710

888

103

123

13

16

728

812

169

187

546

603

*Derived from Anderson (1973) and Arthur D. Little (1974). 
Design parameters for single-family

attached structure *

3 units per building structure. **

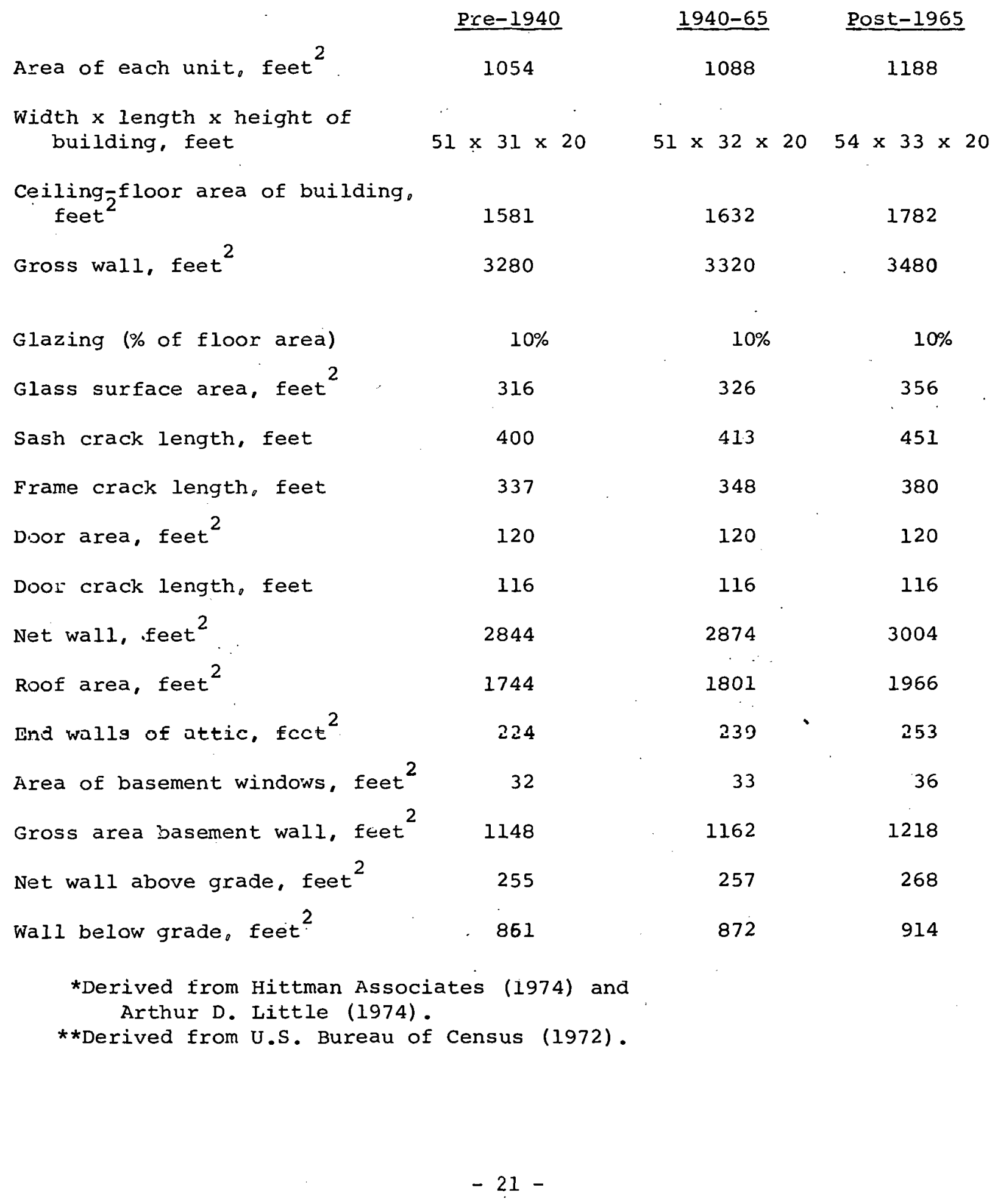




\section{Design Parameter for multi-family \\ low-rise strucutre*}

10 units in building structure**

Area of each unit $=900$ feet $^{2}+126$ feet $^{2}$ of public area. ${ }^{+}$

Width $\mathrm{x}$ length $\mathrm{x}$ height of building, feet

$38 \times 135 \times 20$

Ceiling-floor area of building. feet ${ }^{2}$

5130

Gross wall, feet ${ }^{2}$

6920

Glazing (\% of sidewalls)

20

Glass area, feet $^{2}$

1080

Sash crack length, feet

1368

Frame crack length, feet

1152

Door area, feet ${ }^{2}$

Door crack length, feet

Net wall. feet $^{2}$

Roof ared, fcct ${ }^{2}$

5790

End walls of attic, feet ${ }^{2}$

Area of basement windows, feet ${ }^{2}$

103

Gross area basement walls, feet ${ }^{2}$

Net wall above grade, feet ${ }^{2}$

Wall below gradc, feet ${ }^{2}$

* Derived from Hittman Associates (1974) and Arthur D. Little (1974).

**Derived from U.S. Bureau of Census (1972).

tDerived from Hittman Associates (1974). 


\section{Design parameters for multi- \\ family high-rise structure *}

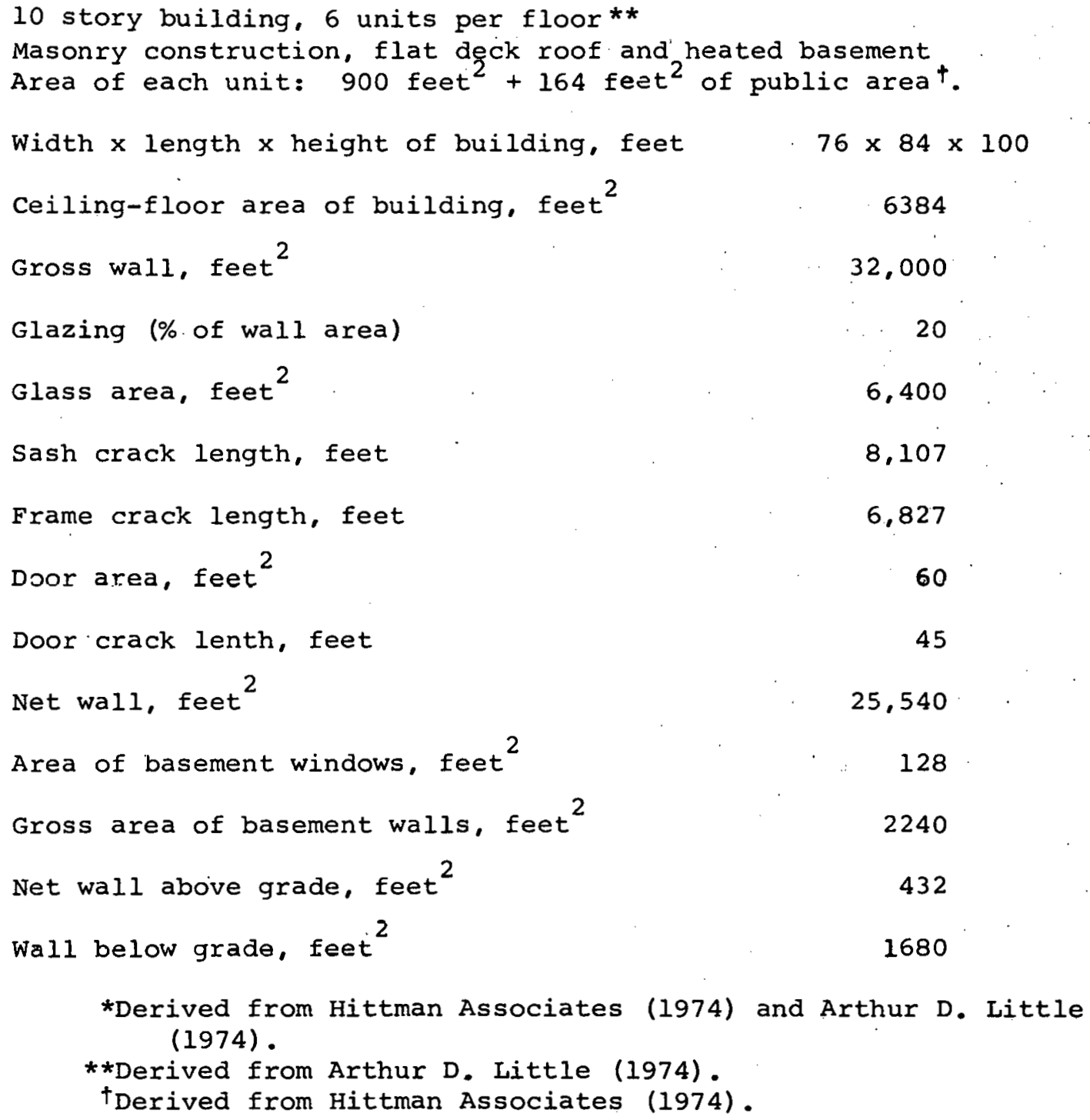

Net wall above grade, feet $^{2}$

wall below grade, feet ${ }^{2}$

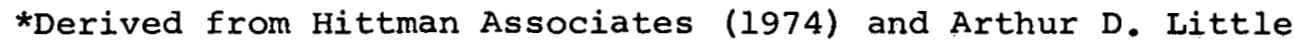
(1974).

**Derived from Arthur D. Little (1974).

tDerived from Hittman Associates (1974). 


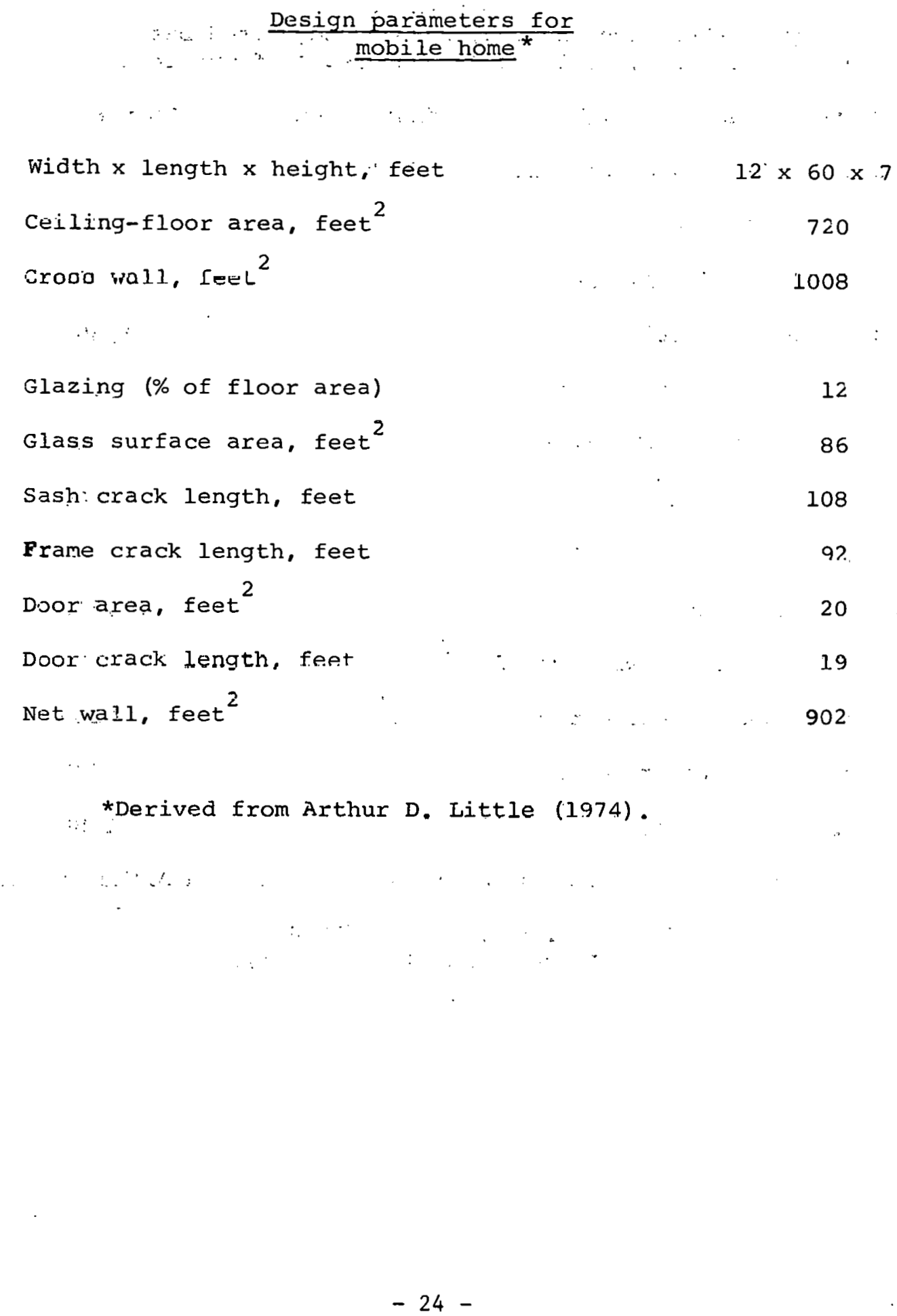




\section{Appendix 2}

Coefficients of Transmission for the Structural Components of Prototypical

Buildings 
Coefficients of transmission for the structural components of SFD, SFA and MFLR

\section{Coefficients of transmission of ceiling} and pitched roof

\begin{tabular}{|c|c|c|}
\hline \multicolumn{3}{|c|}{$\underline{\text { Roof }}$} \\
\hline Construction & Resistance (heating) & Resistance (cooling) \\
\hline Outside surface & $.17^{*}$ & $.25 * *$ \\
\hline Asphalt shingle & .44 & .44 \\
\hline Building paper & .06 & .06 \\
\hline Plywood deck (0.5 in.) & .62 & .62 \\
\hline \multirow[t]{3}{*}{ Inside surface } & .62 & $.83^{\dagger}$ \\
\hline & $\mathrm{R}=1.91$ & $r=2 . \overline{20}$ \\
\hline & $\mathrm{u}=.53$ & $u=.45$ \\
\hline $\begin{array}{l}\text { Frame corrected } \\
(2 \times 4 \text { in. @ } 16 \text { in. inte }\end{array}$ & $\underset{\operatorname{erval}}{u}=.42$ & $\mathrm{u}=.35$ \\
\hline
\end{tabular}

\section{Ceiling}

Construction

Attic surface

Metal lathe and $3 / 4$

in. plaster

Inside surface

\section{Resistance (heating)} .61

.47

$K=\frac{.61}{1.69}$
Resistance (cooling)

.92

.47

$R=\frac{.92}{2.31}$

*Winter conditions (15 mph wind)

** Summer conditions ( $7.5 \mathrm{mph}$ wind)

tValue obtained by linear interpolation (roof assumed to have $25^{\circ}$ pitch). 


\section{Coefficients of transmission of ceiling} with different levels of insulation

$$
\text { ceiling u-value * }
$$

\begin{tabular}{ccc} 
Ceiling insulation level & $\frac{\text { winter }}{0.34}$ & $\frac{\text { summer }}{0.28}$ \\
\hline$R-0$ & 0.11 & 0.10 \\
$R-7$ & 0.080 & 0.076 \\
$R-11$ & 0.051 & 0.050 \\
$R-19$ & 0.042 & 0.041
\end{tabular}

* Corrected for frame of $2 \times 8$ in. at 16 in. intervals. 


\section{Coefficients of transmission of}

frame wall

Construction

Outside surface*

Wood siding, $\frac{3}{2}$ in. $x 8$ in.

Building paper

Sheathing:

plywood, $\frac{3}{2}$ in.

asphalt impregnated, $\frac{1}{2}$ in.

Air space

Insulation

Dry wall:

plaster, $3 / 4 \mathrm{in}$.

gypsum board

Inside surface

Level of insulation

$$
\underline{R-0} \underline{R-7} \quad \underline{R-11}
$$

$\begin{array}{lll}.17 & .17 & .17\end{array}$

$\begin{array}{lll}.81 & .81 & .81\end{array}$

$.06 \quad .06 \quad .06$

1.32

1.32

.97

.97

0

$\begin{array}{lll}0 & 7 & 11\end{array}$

11

17

1

06 


\section{Coefficients of transmission of unheated basements}

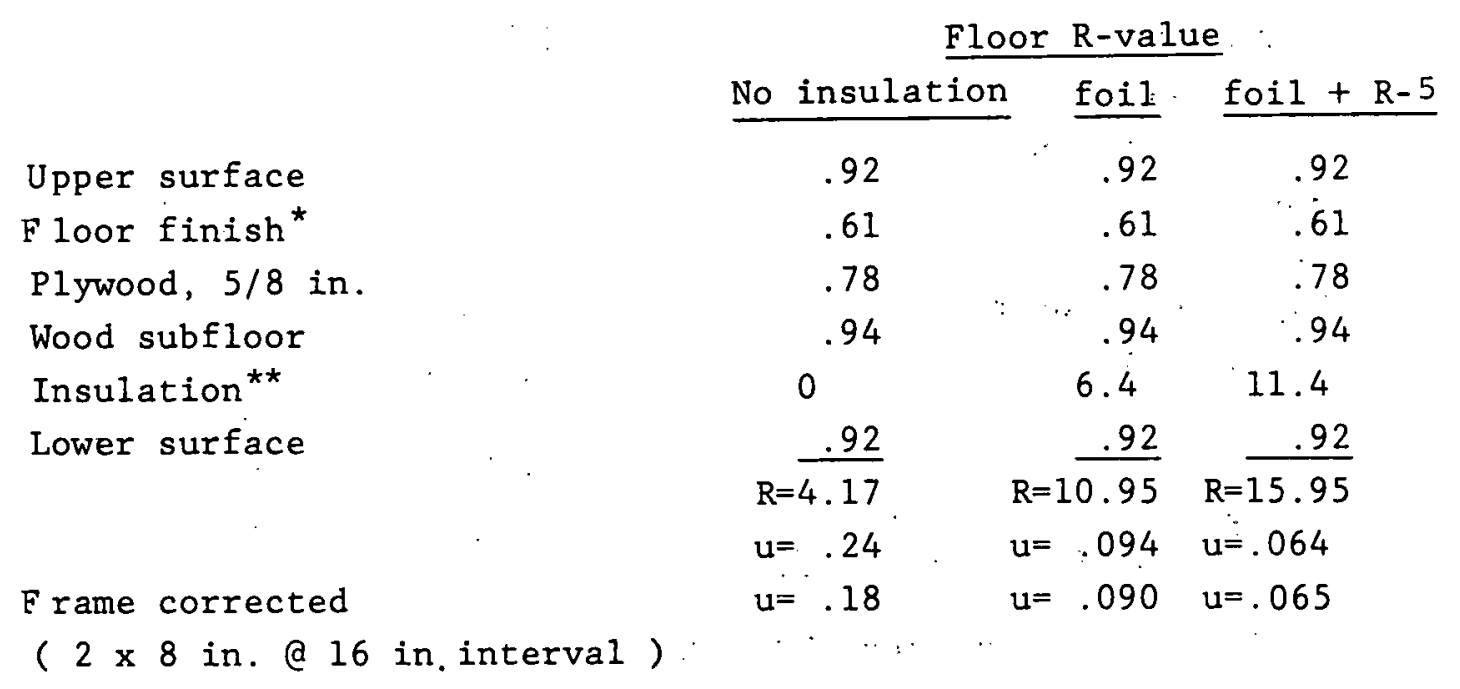

* loor finish assumed to be $20 \%$ tile, $45 \%$ carpeted, and $35 \%$ hardwood. (ASHRAE, 1972 and U.S. Department of Housing and Urban Development, 1973.)

* Foil is considered to offer resistance to downward heat flow approximately equivalent to 2 in. of fiberglass. (Cohen and White, 1975, p. 54.) 


\section{Coefficients of transmission for structural components of MFHR}

Walls

\section{Construction}

Outside surface

4 in. brick

Air space

Concrete block

Air space

Insulation

Gypsum wallboard

Inside still air
Wall $R$ - value

\begin{tabular}{|c|c|}
\hline uninsulated & insulated \\
\hline 0.17 & 0.17 \\
\hline 0.80 & 0.80 \\
\hline 0.97 & 0.97 \\
\hline 0.71 & 0.71 \\
\hline 0.97 & -- \\
\hline-- & $5.25^{\star}$ \\
\hline 0.45 & 0.45 \\
\hline 0.68 & 0.68 \\
\hline$R=4.75$ & $R=9.03$ \\
\hline $\mathrm{u}=0.21$ & $\mathrm{u}=.11$ \\
\hline$u=0.21$ & $\mathrm{u}=.12$ \\
\hline
\end{tabular}

${ }^{\star} 1 \frac{2}{4}$ in. of urea formaldehyde.

Roof

Construction

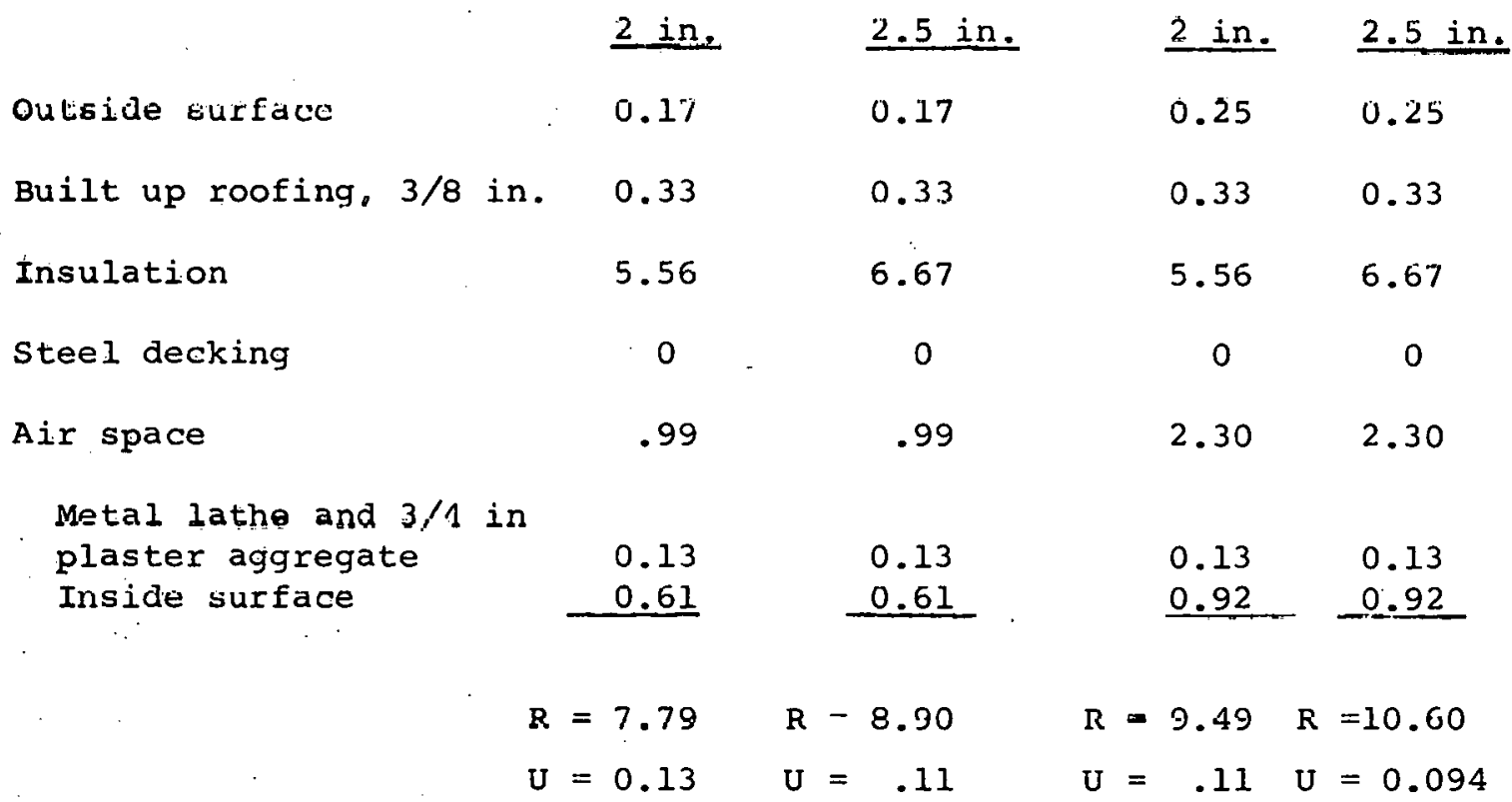


III Coefficients of Transmission for the structural Components of Mobile Homes

Walls

\section{Construction}

Outside surface

Precoated aluminum siding

Fiberglass, 2.5 in.

Plywood, 1/8 in.

Inside surface
Resistance

0.17

0.61

$?$

0.16

0.68

$\mathrm{R}=8.62$

$\mathrm{U}=.12$

\section{Ceiling}

\section{Construction}

Outside surface

30 gauge steel roof

Fiberglass, 3.5 in.

panels。1/4 in.

Inside air

\section{Resistance}

Heating

Cooling

.17

.25

1.10

1.10

11

11

$\begin{aligned} & .62 \\ & R=13.50 \\ & U=0.074\end{aligned} \quad R=\begin{gathered}.62 \\ \text { R }\end{gathered} \quad \begin{gathered}13.89 \\ 0.072\end{gathered}$

Floor

Construction

Upper surface

vinyl tile, $1 / 8$ in.

Particle board

Fiberylass, $3 / 5$ in.

Bottom surface
.92

.61

.05

.05

.82

.02

11

11

Resistance

Cooling

.92

$-.61$

$R=13.71$

$R=13.09$

$U=0.073$

$R=0.076$ 

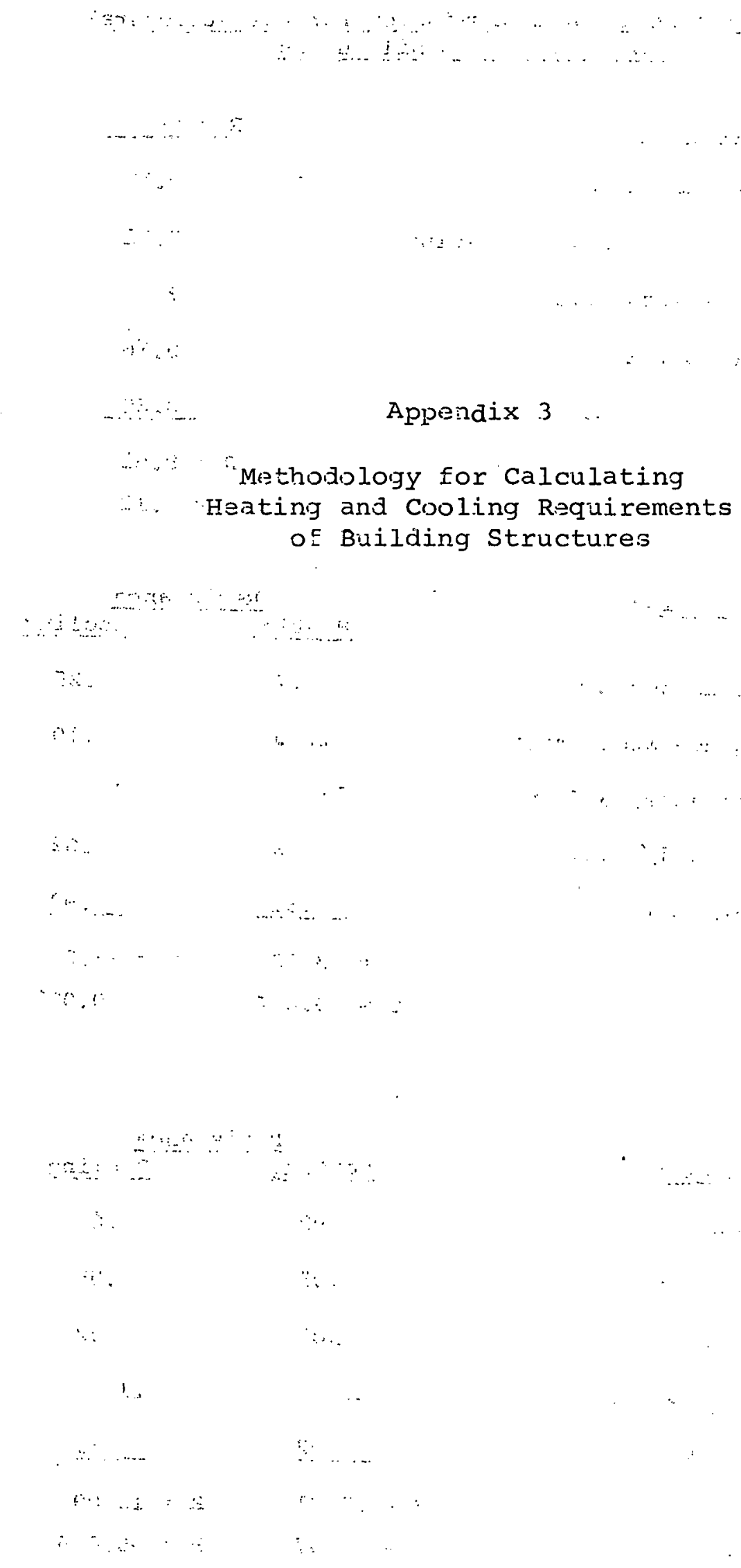


\section{DETERMINATION OF HEATING REQUIREMENTS}

Three basic heat flow componcnts determine the heating requirement of a structure. Heat can he transmitted in or out of a building by conduction through a surface or through the infiltration of outside air and the exfiltration of inside air. The other component results from internal heat gain associated with the presence of occupants and the use of lights and appliances. These three modes of heat transfer will be analyzed in turn.

1. Transmission Heat Losses

Transmission heat losses, except for ceilings under attics or floors over unheated basements, are calculated by the following equation:

$$
\begin{aligned}
\text { Heat loss } & (\mathrm{BTU})=\mathrm{U} \times \mathrm{A} \times \mathrm{HH} \times \Delta \mathrm{T} \\
\text { where: } \mathrm{U} & \left.=\mathrm{U} \text {-value (BTU/hr-ft } \mathrm{fl}^{\circ} \mathrm{F}\right) \\
\mathrm{A} & =\text { surface area }\left(\mathrm{ft} \mathrm{t}^{2}\right) \\
\mathrm{HH} & =\text { number of heating hours (5472 for New England) } \\
\Delta \mathrm{T} & =65^{\circ} \mathrm{F}-\frac{\text { degree days }}{\text { heating days }}\left(28^{\circ} \mathrm{F}\right. \text { for New England) }
\end{aligned}
$$

In the case of ceilings under attics or floors over basements, the temperature prevailing within the attic or basement must be calculated before the temperature differential is determined:

$$
\begin{aligned}
& \Delta T=t_{i}-t_{a / b} \\
& \text { where: } t_{i}=\text { inside air temperature } \\
& \text { ( } 70^{\circ} \mathrm{F} \text { is the value used by HUD) } \\
& t_{a / b}=\text { temperature in attic or basement. }
\end{aligned}
$$

To calculate the attic temperature, $t_{a}$, the following equation is used:

$$
\begin{aligned}
& t_{a}=\frac{\Lambda_{c} U_{c} t_{i}+t_{0} A_{r} V_{r}+A_{W} U_{w}+1.08 A_{C} V}{A_{C} U_{C}+A_{r} U_{r}+A_{w} U_{w}+1.08 A_{C} V} \\
& \text { where: } t_{a} \text { is computed at average } t_{0}=65_{F}^{\circ}-\frac{\text { degree days }}{\text { heating days }}
\end{aligned}
$$

$$
\begin{aligned}
& \mathrm{V}=\text { ventilation rate }\left(.1 \mathrm{ft}^{3} / \mathrm{min} . / \mathrm{ft}^{2} \text { ceilinq }\right) \\
& 1.08=\text { specific heat of air } \mathrm{x} \text { density of air } \\
& \mathrm{x} \text { minutes per hour }
\end{aligned}
$$

and subscripts: $\quad c=$ ceiling

$$
\begin{aligned}
& r=\text { roof } \\
& w=\text { end walls of attic }
\end{aligned}
$$


The temperature of unheated basements, $t_{b}$ is calculated by:

$$
\begin{gathered}
t_{b}=\frac{A_{f} U_{f} t_{i}+t_{o} A_{G} U_{G}+A_{w 1} U_{w 1}+t_{g} A_{b} U_{b}+A_{w 2} U_{w 2}}{A_{f} U_{f}+A_{G} U_{G}+A_{w 1} U_{w 1}+A_{b} U_{b}+A_{w 2} U_{w 2}} \\
\text { where: } t_{g}=\text { ground water temperature }\left(49.2{ }^{\circ}\right. \text { for New } \\
t_{b} \text { is computed at average } t_{0}=65^{\circ}-\frac{\text { degree days }}{\text { heating days }} \\
U_{b}=.1 \\
U_{w 1}=.5 \\
U_{w 2}=.2
\end{gathered}
$$

with subscripts: $f=$ floor over basement

$$
\begin{aligned}
\mathrm{G} & =\text { window } \\
\mathrm{w} 1 & =\text { wall above grade } \\
\mathrm{w} 2 & =\text { wall below grade } \\
\mathrm{b} & =\text { basement floor }
\end{aligned}
$$

The temperature differential, $\Delta T$, can then be replaced in equation (1) using the appropriate U-value and area for the floor or ceiling (Petersen。 1974).

In the case of heated basements, heat loss through the walls above grade and windows are calculated by equation (1), based on the following coefficients of transmission:

$$
\begin{aligned}
& \mathrm{U}_{\mathrm{W}}=0.5 \\
& \mathrm{U}_{\mathrm{G}}=1.0
\end{aligned}
$$

However, heat losses through the basement and wall below grade are considered a simple function of the water temperature (ASHRAE, 1972 , P. 378).

Ground Water

Temperature $49.2^{\circ} \mathrm{F}$

$$
\begin{aligned}
& \text { (B'l'U/ft') } \\
& \frac{\text { Basement floor loss }}{2.08} \quad \frac{\text { Below grade wall loss }}{4.16}
\end{aligned}
$$

\section{Infiltration Heat Losses}

Infiltration is the second component of transfer of heat to and from a residence. It takes place by way of air flow through openings in the external surfaces of the residence. Wind action and temperature differences between the interior and the exterior of the residence (chimney or stack effect) are the driving forces that are responsible for infiltration heat transfer (Anderson, 1973).

a. Wind forces. When a pressure difference between the inside and the outside of a building is the result of wind pressure, air will enter the building through openings in the wind- 
ward walls and leave through openings in the leeward walls. Once the proper assumption are made about window or door type, infiltration heat losses can be readily calculated by an equation similar to (1):

Heat loss $(\mathrm{BTU})=\mathrm{B} \times \mathrm{L} \times \mathrm{HH} \times \Delta \mathrm{T}$

where: $B=$ infiltration coefficient (BTU/hr-ft- ${ }^{\circ} \mathrm{F}$ )

$L=$ crack length $(f t)$

$\mathrm{HH}$ and $\Delta \mathrm{T}$ have the same values as in equation (1).

The following infiltration coefficients were derived for doors and windows (Petersen, 1974):

- Windows: Description

1) Loose fit without weatherstrip Infiltration coefficients (BTU/hr-ft-OF)

2) Average fit without weatherstrip or loose fit with weatherstrip - Window Type

3) Average fit with weatherstrip $\frac{\text { Single }}{0.591}, \frac{\text { Storm }}{0.296}$

- Doors

0.209

0.107

0.146

0.096

Infiltration coefficients (BTU/hr-ft-F)

\section{Description}

1) Well fitted door

2) Average/poor fitted
Simple Door Weatherstripping $\frac{\text { Without }}{0.418} \frac{\text { With }}{0.209}$

\section{Storm Door} Weatherstripping Without With $\overline{0.293} \overline{0.188}$
1.33
0.665
$0.665 \quad 0.466$

Pre-1965 buildings were assumed to have loose fit windows and average-to-poor fitted doors. All more recent building construction was assumed to have the better fitting doors and windows.

b. Temperature difference forces. The stack effect is the result of temperature differences between the inside and the outside of a building. When the inside temperature is hiqher than the outside, this effect produces a nogative pressure and inward flow of air at lower levels, and a positive and upward flow at higher levels.

The stack and wind effect are not additive. The pattern of pressure differences across a building enclosure depends on the magnitude of all acting forces and the distribution of openings into and within the building.

The stark effect is difficult to evaluate, even when considered to act independently. However, an equation is available providing a total estimate of infiltration. The Achenbach-Coblentz 
equation is based on experimental measurements of actual homes and is of the form (Anderson。' 1973):

$$
I=A+B V+C|\Delta T|
$$

where: I = infiltration rate, air changes per hour

$\mathrm{V}=$ wind speed, miles per hour

$\Delta T=$ temperature difference between the interior of the residence and outside. $F$.

$\mathrm{C}=0.00833$

The last term of this linear equation measures the stack effect. Its use may have lead to an over estimation of infiltration since the wind effect was considered to be independent. This expression has been applied to all buillings, except the mobile home where it was neglected- Extrapolating this term to calculate the stack effect for the MFHR can only be considered a very rough approximation. While the stack effect demonstrates an increase with building height, it decreases with the increased integrity of each floor to infiltration, be it within or between floors.

c. Other infiltration. Other sources of infiltration arise from the use of mechanical ventilation and air breathing equipment. The daily average flow rates are shown in Table $A$ and must be construed as rough approximations. They were originally calculated for a prototypical gas heated home and have been adapted for use with all the housing stock.

\section{Internal Heat Load}

The internal heat load is the sum of three major components: lighting, appliances and occupants. This heat load reduces heating requirements in winter and increases cooling loads in the summer. The calculation of the internal heat qain for a house in the Washington-Baltimore area with 200 heating days is $13.5 \times 10^{6}$ BTU. This was increased for the New England area to reflect the longer heating season. Further, an assumption was made that internal heat loads are proportional to the surface area. Thus the internal heat loads is assumed to be $9.09 \times 10^{3} \mathrm{BTU} / \mathrm{sq} \mathrm{ft} / \mathrm{heating}$ season.

\section{DETERMINATION OF COOLING REQUIREMENTS}

'l'he method tor calculating covling loads resembles closely that to calculate heating loads:

$$
\begin{aligned}
& \text { Heat gain (BTU) }=U \times A \times C H \times \Delta T \\
& \text { Where: } U=U \text {-value (BTU/hr-ft } t^{2}-F \text { ) } \\
& A=\text { surface area (ft }) \\
& \mathrm{CH}=\text { number of cooling hours (400 for New England). }
\end{aligned}
$$


Table A

Daily Average Air Flow Rates *

Mechnical ventilation (for both fossil fuel and electric heated homes) Fans 12.0 CFM $x .264^{* k}=3.2$ CFM

door openings $4.25 \mathrm{CFM} /$ occupant $t$

Air Breathing Equipment (fossil fuel heated homes only) Furnace $0.331 \mathrm{CFM} / 10^{\circ}$ BTU Heating Requirements Hot water heater $2.12 \mathrm{CFM} /$ Occupant

* Source $=$ Adapted from Anderson, (1973) p. 33

* * Saturation derived from FHA homes, (1973).

† SFD, SFA: 4 occupants/unit

MFLR: 3 occupants/unit

MFHR: 1.5 occupants/unit

MOBILE: 2 occupants/unit 
$\Delta \mathrm{T}=$ Temperature differential based on "Design equivalent temperature differences" (ASHRAE, 1972, p. 441, Table 50). Medium temperature ranges and a design temperature of $900 \mathrm{~F}$ were used for the walls, doors and flat roof.

Floors over basements do not contribute to cooling load requirements. However。 in the case of ceilings under attics。 it was necessary to take account of the temperature prevailing with the attic to calculate the temperature differential (Petersen, 1974, p. 56):

$$
t_{a}=\frac{{ }_{C} U_{c} t_{i}+A_{r} U_{r} t_{s r}+A_{w} U_{w} t_{s w}+1.08 A_{c} V_{t o}}{A_{C} U_{C}+A_{r} U_{r}+A_{w} U_{w}+1.08 A_{C} V}
$$

where: $t_{\text {sr }}=\cdot$ sol air temperature equivalent of roof $\left(110^{\circ} \mathrm{F}\right.$ for New England)

$t_{\text {sw }}=$ sol air temperature equivalent of walls (91.10F for New England)

$t_{0}=$ outside dry bulb temperature $\left(90^{\circ} \mathrm{F}\right.$ for New England)

$t_{i}=$ interior temperature $\left(75^{\circ} \mathrm{F}\right)$

Heat gain through windows was calculated by using a parameter dependent on the buildings orientation as well as the type of shading. Hittman Associates (1974) considers that $70 \%$ of the windows have drapes, $20 \%$ have shades and $10 \%$ are open. These same proportions were used to derive a value applicable to all housing type. The glazing distribution was then derived from the literature and ficld observation:

Type of

Structure

SFD

SFA

MFLR

MFHR

MOBILE

$\frac{N}{35 \%}$
$37.5 \%$
$45.0 \%$
$42.5 \%$
40.036

Distribution of glazing

\begin{tabular}{ll}
$\mathrm{E}-\mathrm{W}$ & $\frac{S}{40 \%}$ \\
\hline $25 \%$ & $45.0 \%$ \\
$17.5 \%$ & $55.0 \%$ \\
$--0-$ & $42.5 \%$ \\
$15.0 \%$ & $40.0 \%$ \\
$20 \%$ &
\end{tabular}

Natural leakage in winter is much sillallex than in summer. The chimney effect is, of course, absent in summer and the wind velocity is considered to be $50 \%$ lower. A value of $1.1 \mathrm{BTU} / \mathrm{hr}$ per square foot of exposed gross wall surface area is used to calculate natural infiltration (ASHRAE, 1972, p. 442).

The sum of the heat gain from the various structural components, the sensible heat gain, is multiplied by 1.105 to give the component load. This multiplier is itself the product of 1.3 , to account for latent heat gain, and 0.85, a "use factor"。 Dole (1975) assumes an $85 \%$ use factor for air conditioners to account for the fact that many housing units are empty during the day. Finally。 an internal heat gain factor is added to the component load based on assumptions similar to those for heating. The internal heat load is assumed to be $2.37 \times 10^{3} \mathrm{BTU} / \mathrm{sq}$ 。ft/ cooling season. 
Appendix 4

Heating Requirements of Prototypical Building Structures 
$\begin{array}{r}\text { Structure } \\ \text { Category } \\ \hline\end{array}$

Transmission Heat Losses

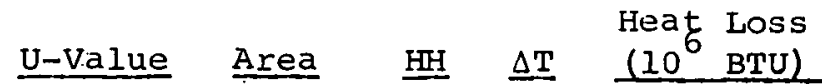

SFD - walls

R-11

1972-1985

$\begin{array}{cc} & - \text { ceiling roof } \\ \text { electric } & \text { R-24 }\end{array}$

- Jasemenl rluor

$\mathrm{R}-5$ + foil

$\begin{array}{lllll}0.073 & 1806 & 5472 & 28 & 20.2\end{array}$

$-24$

0.042

805

$5472 \quad 39.3$

7.3

-windows

$100 \%$ storm (metal)

0.065

80

547

24.2

6.9

-doors

$100 \%$ storm

$\begin{array}{lllll}0.56 & 242 & 5472 & 28 & 20.7\end{array}$

0.27

$\begin{array}{lll}40 & 5472 \quad 28\end{array}$

1.7

Infiltration Heat Losses

B-coef. length

-sash crack

weatherstrip

0.0954

307

5472

28

4.5

-frame crack caulk

0.029

258

$5472 \quad 28$

1.2

-door

weatherstrif

0.19

$39 \quad 5472 \quad 28$

1.1

-stagk effect

9.3

-air breathing* equipment

3.3

Internal Heat Load

$-14.6$

Unit demand

61.6

*Includes mechanical ventilation. 


\section{Structure}

Category Transmission Heat Losses

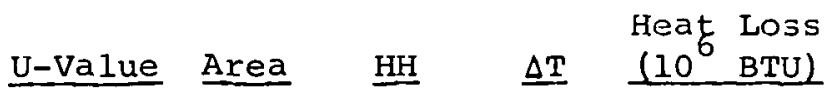

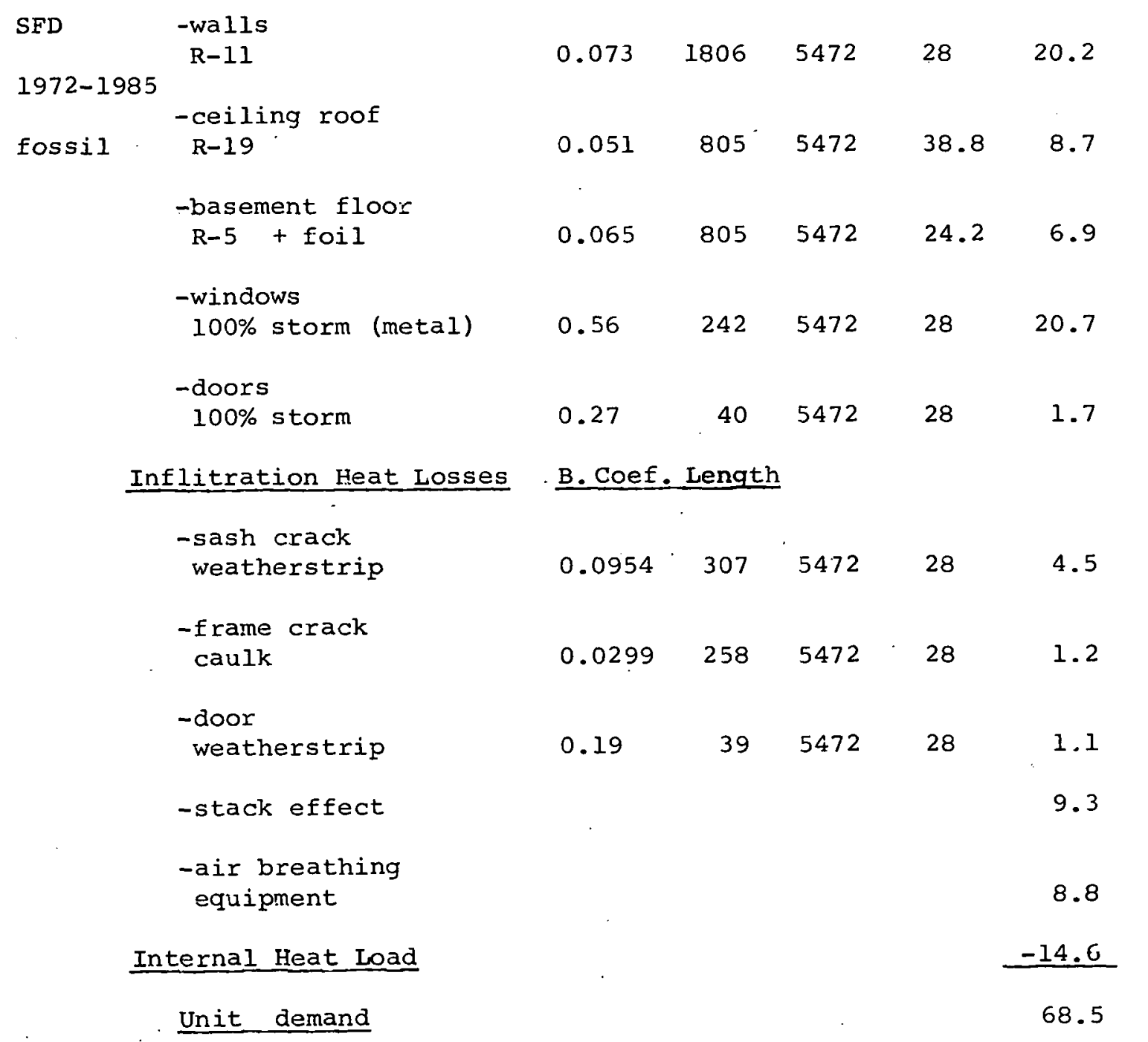


Structure

$\underline{U-V a l u e ~ A r e a ~} \underline{\mathrm{HH}} \quad \underline{\Delta T \quad \underline{\left(10^{6} \mathrm{BTU}\right)}}$

\begin{tabular}{|c|c|c|c|c|c|c|}
\hline SFD & $\begin{array}{c}\text {-walls } \\
\text { R-1l }\end{array}$ & 0.073 & 1806 & 5472 & 28 & 20.2 \\
\hline $1965-1972$ & & & & & & \\
\hline electric & -ceiling roof & & & & & \\
\hline & $R-19$ & 0.051 & 805 & 5472 & 38.8 & 8.7 \\
\hline & -basement floor & & & & & \\
\hline & $R-5+$ foil & 0.065 & 805 & 5472 & 24.2 & 6.9 \\
\hline & -windows & & & & & \\
\hline & $100 \%$ storm (metal) & 0.56 & 242 & 54.72 & 28 & 20.7 \\
\hline & -doors & & & & & \\
\hline & $100 \%$ storm & 0.27 & 40 & 5472 & 28 & 1.7 \\
\hline In & filtration Heat Losses & B. Coef & Leng & & & \\
\hline & -sash crack & 0954 & 307 & 5472 & 28 & 45 \\
\hline & -frame crack & & & & & \\
\hline & caulk & 0.0299 & 258 & 5472 & 28 & 1.2 \\
\hline & -door & & & & & \\
\hline & weatherstrip & 0.19 & 39 & 5472 & 28 & 1.1 \\
\hline & -stack effect & & & & & 9.3 \\
\hline & $\begin{array}{l}\text {-air breathing } \\
\text { equipment }\end{array}$ & & & & & 3.3 \\
\hline$\underline{I n} 1$ & ternal Heat Load & & & & & -14.6 \\
\hline & Unit domand & & & & & 63.0 \\
\hline
\end{tabular}


Structure

Category Transmission Heat Losses
U-Value Area

$\underline{\mathrm{HH}}$$$
0.073
$$

1806

5472

28

20.2

1965-1972

-ceiling roof

fossil

0.051

805

5472

38.8

8.7

-basement floor

Foil

0.090

805

5472

22.9

6.9

-windows

$75 \%$ storm (metal)

$\begin{array}{lllll}0.702 & 242 & 5472 & 28 & 26.0\end{array}$

-doors

$75 \%$ storm

0.31

40

5472

28

1.9

Infiltration Heat Losses

B Coef, Length

-sash crack

$50 \%$ weatherstrip

$\begin{array}{lllll}.130 & 307 & 5472 & 28 & 6.1\end{array}$

-frame crack

caulk

0.0299

258

5472

28

1.2

-door crack

$50 \%$ weatherstrip

0.259

39

5472

28

1.5

-air breathing

equipment

-stack effect

Internal Heat Load

Unit demand

76.5 
Structure Category

Transmission Heat Losses

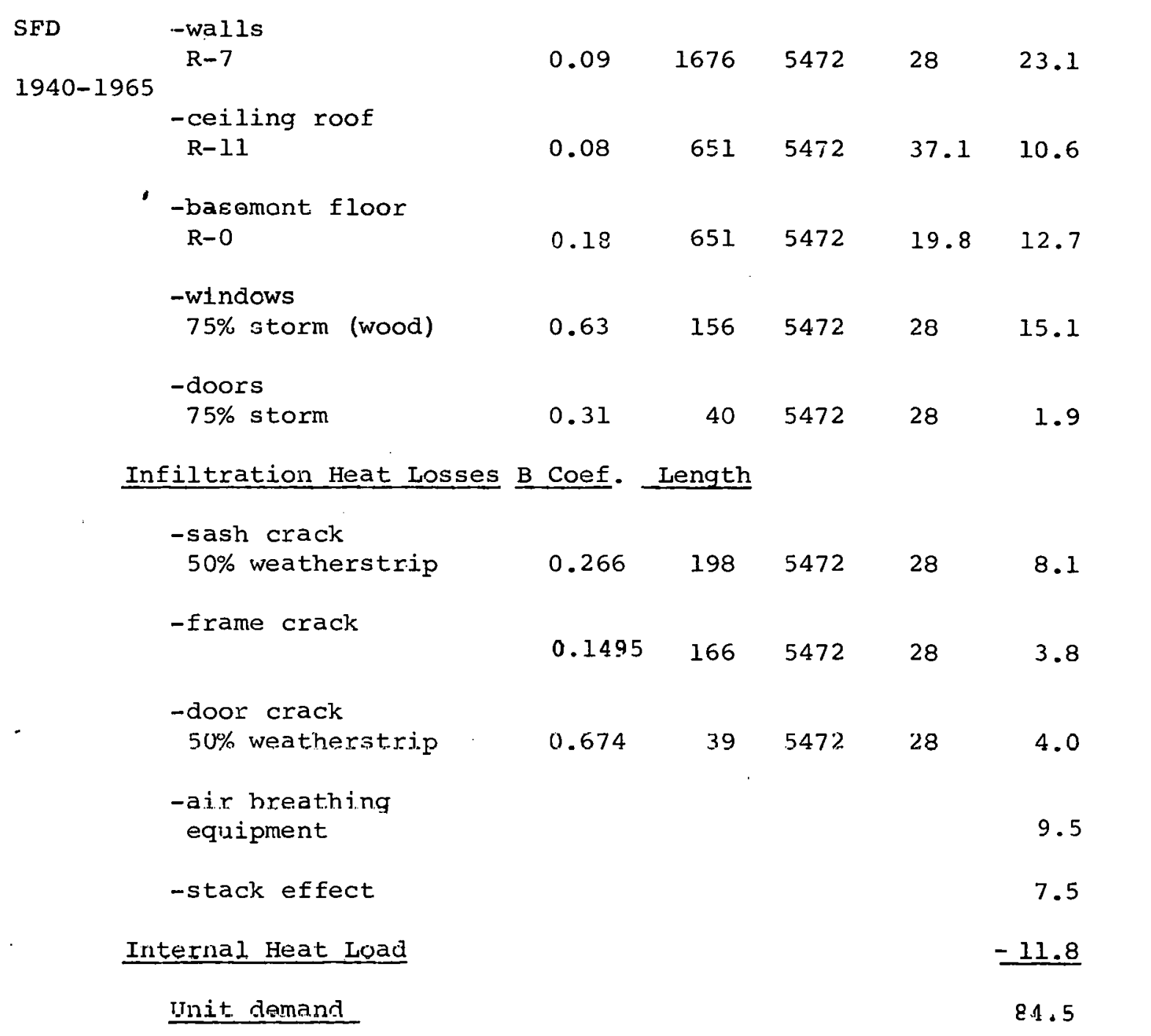


Structure

Category

Transmission Heat Losses

U-Value Area

$\underline{H H}$

Heat Los

SFD -walls

Pre-1940

$90 \% \mathrm{R}-8 \quad 10 \% \mathrm{R}-0$

$\begin{array}{lllll}0.11 & 1616 & 5472 & 28 & 27.2\end{array}$

insulated

-ceiling roof

R-7

$\begin{array}{lllll}0.11 \quad 600 & 5472 & 35.6 & 12.9\end{array}$

-basement floor

R-O

$\begin{array}{lllll}0.18 & 600 & 5472 & 20.0 & 11.8\end{array}$

-windows

$75 \%$ storm (wood)

$\begin{array}{lllll}0.63 & 144 & 5472^{\circ} & 28 & 13.9\end{array}$

-doors

$75 \%$ storm

$\begin{array}{lllll}0.31 & 40 & 5472 & 28 & 1.9\end{array}$

Infiltration Heat Losses

B coef. Length

-sash crack

$50 \%$ weatherstrip

182

5472

28

7.4

-frame crack

.1495

154

5472

28

3.5

-door crack

$50 \%$ weatherstrip

.674

39

5472

28

4.0

-air breathing

equipment

$10: 2$

-stack effect

6.9

Internal Heat Load

$=10.9$

Unit demand

88.8 
Structure

Category Transmission Heat Losses

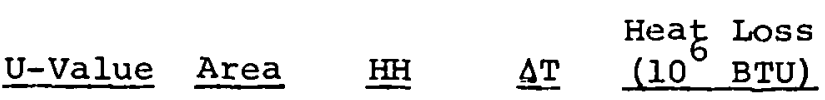

$$
\begin{array}{cc}
\text { SFD } & \text {-walls } \\
\text { R-0 }
\end{array}
$$

Pre- 1940

0.26

1616

5472

28

64.4

uninsulated

-ceiling roof

R-0

0.34

600

5472

27

30.1

- Waseritent floor $\mathrm{R}-0$

0.18

600

$5472 \quad 20.0$

11.8

-windows

$75 \%$ storm (wood)

0.63

144

5472

28

13.9

-doors

$75 \%$ storm

$\begin{array}{lllll}0.31 & 40 & 5472 & 28 & 1.9\end{array}$

Infiltration Heat Losses

B-coef. Length

-sash crack

$50 \%$ weatherstrip

0.266

182

5472

28

7.4

-frame crack

$\begin{array}{lllll}0.1495 & 154 & 5472 & 28 & 3.5\end{array}$

-door crack

$50 \%$ weatherstrip

0.674

3

5472

28

4.0

- הir hraathing

equipment

12.7

-stack effect

Internal reat Ioad

Unit demend

$-10.9$

145.7 
Structure

Categor

Transmission Heat Losses

U-Value Area

$\underline{\mathrm{HH}}$

Heat Loss

SFA $\quad-$ walls

1972-1985

-walls

-ceiling roof

electric $R-24$

$\begin{array}{lllll}0.073 & 3004 & 5472 & 28 & 33.6\end{array}$

-basement floor

$\mathrm{R}-5+$ foil

$\begin{array}{lllll}0.065 & 1782 & 5472 & 22.6 & 14.4\end{array}$

-windows

$100 \%$ storm (metal)

0.56

$356 \quad 5472$

28

30.5

-doors

$100 \%$ storm

$\begin{array}{lllll}0.27 & 120 & 5472 & 28 & 5.0\end{array}$

Infiltration Heat Losses

B-coef. Length

-sash crack

weatherstrip

$\begin{array}{lllll}0.0954 & 451 & 5472 & 28 & 6.6\end{array}$

-framc crack

caulk

$\begin{array}{lllll}0.0299 & 380 & 5472 & 28 & 1.7\end{array}$

-door crack

weatherstrip

$\begin{array}{lllll}0.19 & 116 & 5472 & 28 & 3.4\end{array}$

-air breathing

equipment (includes mechanical ventilation)

10.0

-stack effect

22.9

Internal Heat Loàd

$-32.4$

Unit demand

111.8 
Structure Category

Transmission Heat Losses

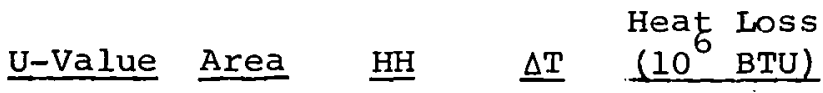

\begin{tabular}{|c|c|c|c|c|c|c|}
\hline SFA & $\begin{array}{c}\text {-walls } \\
\mathrm{R}-11\end{array}$ & 0.073 & 3004 & 5472 & 28 & 33.6 \\
\hline $1972-1985$ & -ceiling roof & & & & & \\
\hline fossil & $R-19$ & 0.051 & 1782 & 5472 & 38.8 & 19.3 \\
\hline & $\begin{array}{l}\text {-basement floor } \\
R-5+\text { foil }\end{array}$ & 0.065 & 1782 & 5472 & 22.6 & 14.4 \\
\hline & $\begin{array}{l}\text {-windows } \\
100 \% \text { storm (meta } 1 \text { ) }\end{array}$ & 0.56 & 356 & 5472 & 28 & 30.5 \\
\hline & $\begin{array}{l}\text {-doors } \\
100 \% \text { storm }\end{array}$ & 0.27 & 120 & 5472 & 28 & 5.0 \\
\hline
\end{tabular}

Infiltration Heat Losses B-coef.

-sash crack

weatherstrip

$\begin{array}{lllll}0.0954 & 451 & 5472 & 28 & 6.6\end{array}$

-frame crack

caulk

$\begin{array}{lllll}0.0299 & 380 & 5472 & 28 & 1.7\end{array}$

- door crack

wcathoretrip

$0.19 \quad 116 \cdot 5472 \quad 28 \quad 3.4$

-air breathing

equipment

21.0

-stack effect

22.9

Internal Heat Load

$-32.4$

Unit demand

126.8 


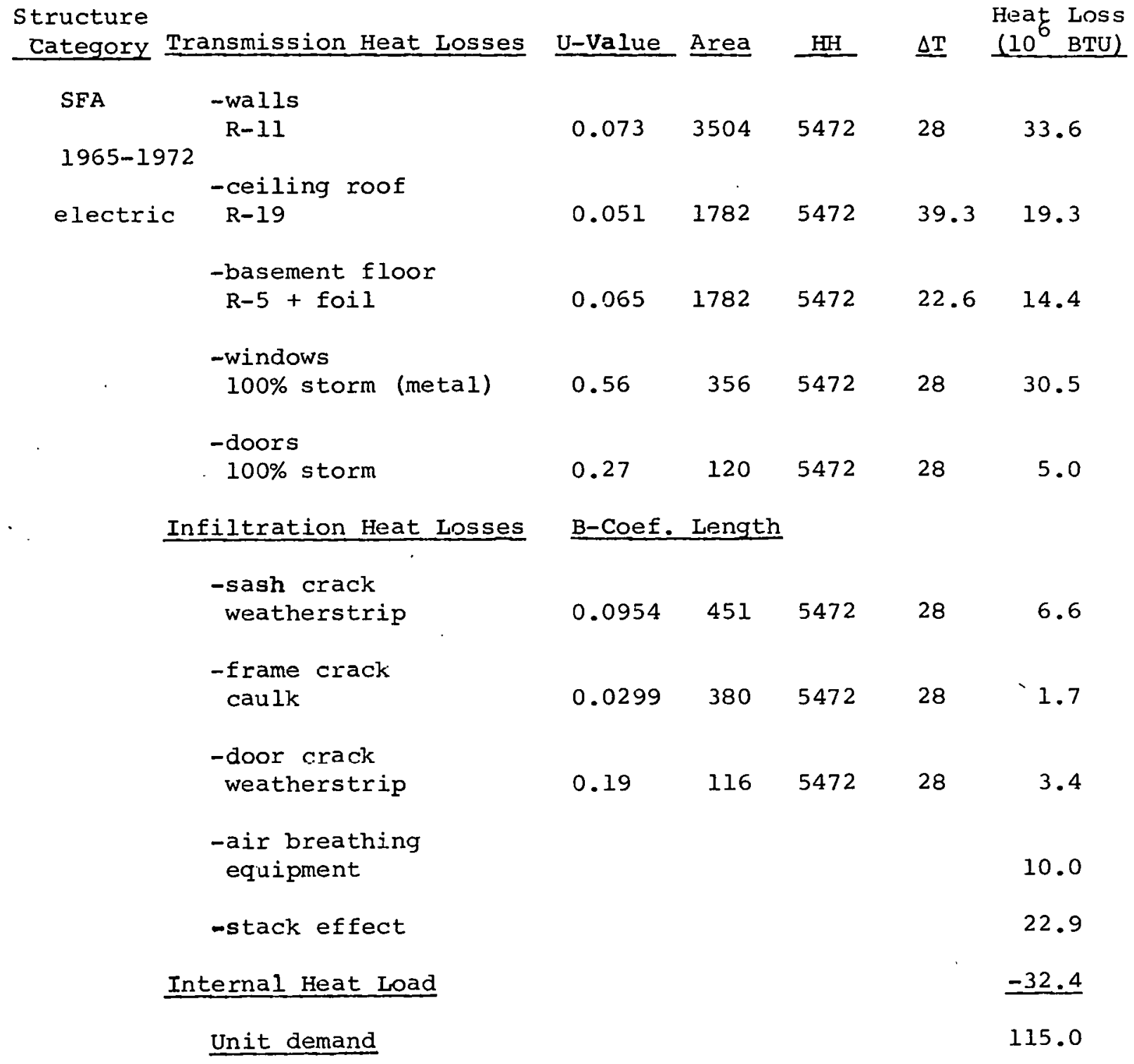


Structure Categor

Transmission Heat Losses

U-Value Area

$\underline{\mathrm{HH}}$

$\underline{\Delta \mathrm{T}} \quad \begin{array}{r}\text { Heat Loss } \\ \left(10^{\circ} \mathrm{BTU}\right)\end{array}$

SFA $\quad$-walls

$$
\begin{array}{lllll}
0.073 & 3004 & 5472 & 28 & 33.6
\end{array}
$$

$1965-1972$

-ceiling roof

fossil R-19

$\begin{array}{lllll}0.051 & 1782 & 5472 & 39.3 & 19.3\end{array}$

-bascment floor

Foil

$0.090 \quad 1782 \quad 5472 \quad 21.2 \quad 18.6$

-windows

$\begin{array}{llllll}75 \% \text { storm (metal) } & 0.702 & 356 & 5472 & 28 & 38.3\end{array}$

-doors

$75 \%$ storm

$\begin{array}{lllll}0.31 & 120 & 5472 & 28 & 5.7\end{array}$

Infiltration Heat Losses B-coef. Length

\begin{tabular}{|c|c|c|c|c|c|}
\hline \multicolumn{6}{|l|}{-sash crack } \\
\hline $\begin{array}{l}\text {-frame crack } \\
\text { caulk }\end{array}$ & 0.0299 & 380 & 5472 & 28 & 1.7 \\
\hline -doo: crack & & & & & \\
\hline $50 \%$ weathercrack & 0.259 & 116 & 5472 & 28 & 4.6 \\
\hline $\begin{array}{l}\text {-air breathing } \\
\text { equipment }\end{array}$ & & & & & 22.7 \\
\hline -stack effect & & & & & 22.9 \\
\hline Internal Heat Ioad & & & & & -32.4 \\
\hline Unit demand & & & & & 144.0 \\
\hline
\end{tabular}


Structure

Category

Transmission Heat Losses

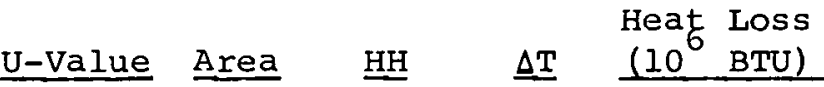

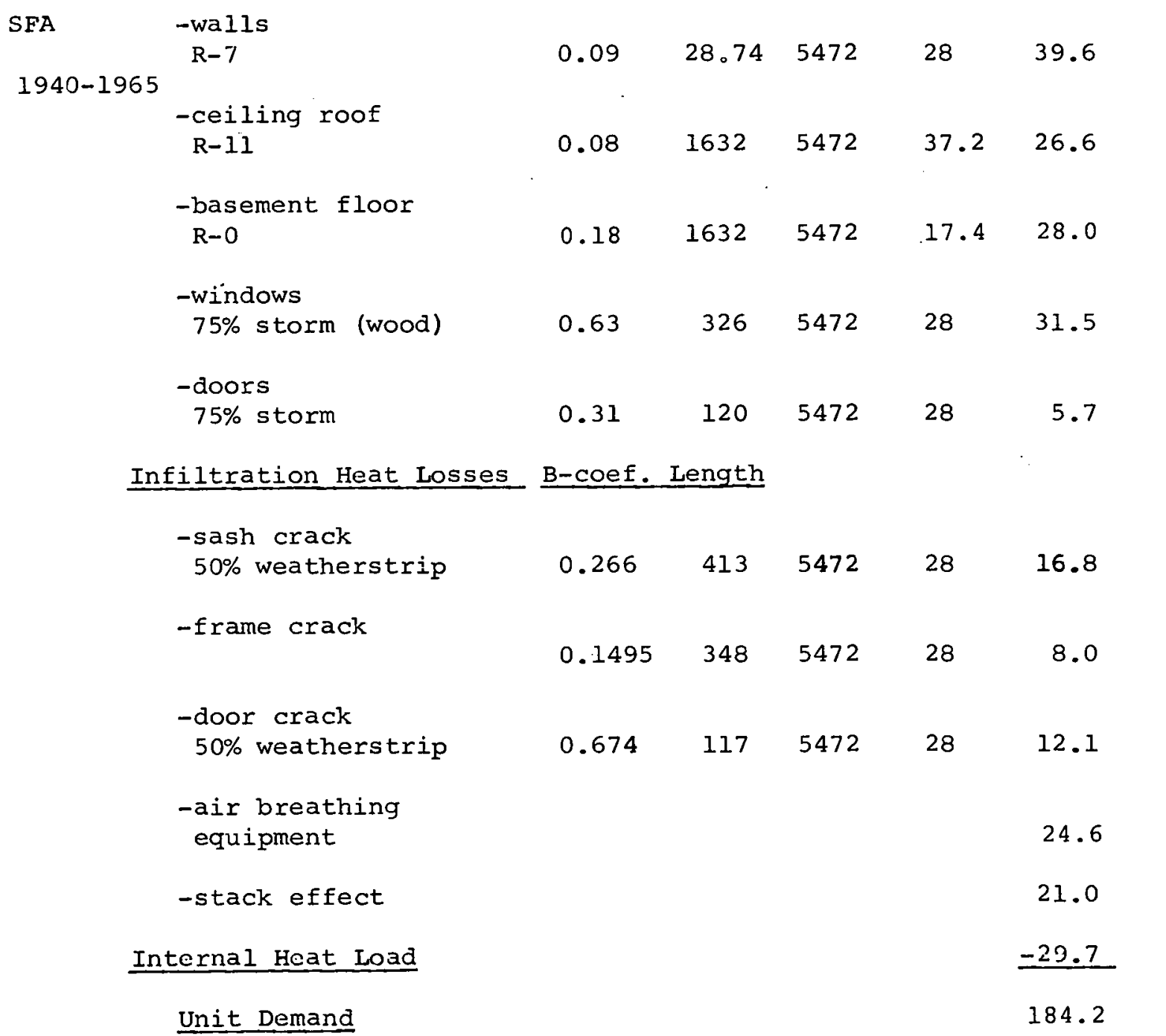


Structure

-Category Transmission Heat Losses

SFA
Pre- 1940
insulated

$$
\text { -wal1s }
$$$$
90 \% \text { R- } 8 \quad 10 \% \text { R-0 }
$$$$
\text { -ceiling roof }
$$$$
\text { R-7 }
$$

-basement flons

R-0

-windows

$75 \%$ storm (wood)

-doors

$75 \%$ sotrm

Infiltration Heat Losses B-Coef. Length

-sash crack

$50 \%$ weatherstrip

-frame crack

-door crack

$50 \%$ weatherstrip

-air breathing

equipment

-stack effect

Internal Heat Load

Unit demand

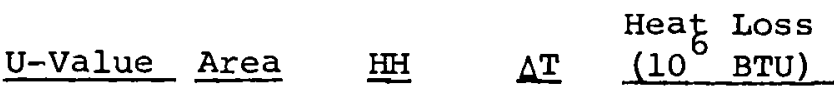

$\begin{array}{lllll}0.11 & 2844 & 5472 & 28 & 47.9\end{array}$

$\begin{array}{lllll}0.11 & 1581 & 5472 & 35.6 & 33.8\end{array}$

$\begin{array}{lllll}0.18 & 1581 & 5472 & 17.5 & 27.3\end{array}$

$\begin{array}{lllll}0.63 & 316 & 5472 & 28 & 30.5\end{array}$

$\begin{array}{lllll}0.31 & 120 & 5472 & 28 & 5.7\end{array}$ 
structure

Category

Transmission Heat Losses

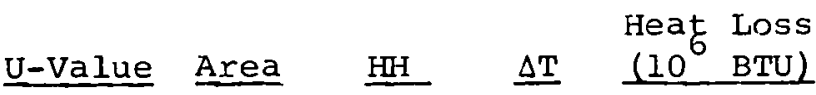

SFA -walls

'Pre-1940

insulated -ceiling roof

$\begin{array}{lllllll}\mathrm{R}-\mathrm{O} & 0.34 & 1581 & 5472 & 26.8 & 79.2\end{array}$

-basement floor

$\begin{array}{llllll}R-0 & 0.18 & 1581 & 5472 & 17.5 & 27.3\end{array}$

-windows

$\begin{array}{lllllll}75 \% & \text { storm (wood) } & .0 .63 & 316 & 5472 & 28 & 30.5\end{array}$

-doors

$\begin{array}{llllll}75 \% \text { storm } & 0.31 & 120 & 5472 & 28 & 5.7\end{array}$

Infiltration Heat Losses B-Coef. Length

\begin{tabular}{lccccc}
$\begin{array}{l}\text {-sash crack } \\
50 \% \text { weatherstrip }\end{array}$ & .266 & 400 & 5472 & 28 & 16.3 \\
-frame crack & .1495 & 337 & 5472 & 28 & 7.7 \\
$\begin{array}{l}\text {-door crack } \\
50 \% \text { weatherstrip }\end{array}$ & .674 & 117 & 5472 & 28 & 7.7 \\
$\begin{array}{l}\text {-air breathing } \\
\text { equipment }\end{array}$ & & & & 31.3 \\
$\begin{array}{l}\text {-stack effect } \\
\text { ternal Heat Load }\end{array}$ & & & & 19.7 \\
Unit demand & & & & \\
\hline
\end{tabular}


Structure

Category

Transmission Heat Losses

U-Value Area

HHH

Heat Loss

MFLR - walls

1972-1985

$\begin{array}{lllll}0.073 & 5790 & 5472 & 28 & 64.8\end{array}$

-ceiling roof

electric R-24

$\begin{array}{lllll}0.042 & 5130 & 5472 & 39.2 & 46.2\end{array}$

- basement floor

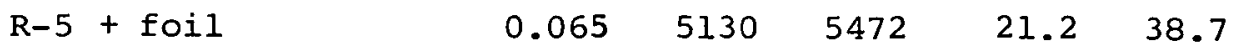

-windows

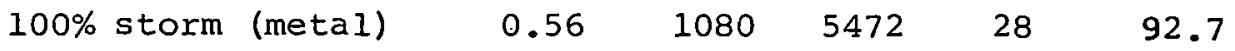

-doors

$\begin{array}{llllll}100 \% \text { storm } & 0.27 & 50 & 5472 & 28 & 2.1\end{array}$

Infiltration Heat Losses B-Coef. Length

-sash crack

weatherstrip

$\begin{array}{lllll}0.0954 & 1368 & 5472 & 28 & 20.0\end{array}$

- frame crack

caulk

$\begin{array}{lllll}0.0299 & 1152 & 5472 & 28 & 5.3\end{array}$

-door crack

weatherstrip

$\begin{array}{lllll}0.19 & 48 & 5472 & 28 & 1.4\end{array}$

-air breathing

equipment

26.4

-stack effect

65.9

Internal Heat Load

$-9.3 .2$

Unit Demand

270.3 
Structure

Category

Transmission Heat Losses

MFLR - $\quad$ Ralls

1972-1985

fossil -ceiling roof

fossil R-19

-basement floor

$\mathrm{R}-5$ + foil

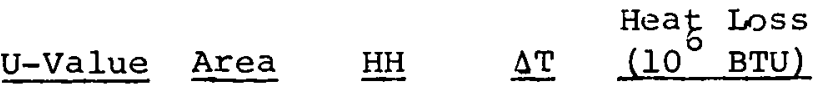

-windows

$100 \%$ storm (metal)

$\begin{array}{lllll}0.073 & 5790 & 5472 & 28 & 64.8\end{array}$

-doors

$100 \%$ storm

0.27

$50 \quad 5472$

28

2.1

Infiltration Heat Losses B-Coef. Length

\begin{tabular}{|c|c|c|c|c|c|}
\hline $\begin{array}{l}\text {-sash crack } \\
\text { weatherstrip }\end{array}$ & 0.0954 & 1368 & 5472 & 28 & 20.0 \\
\hline $\begin{array}{l}\text { - frame crack } \\
\text { caulk }\end{array}$ & 0.0299 & 1152 & 5472 & 28 & 5.3 \\
\hline $\begin{array}{l}\text {-door crack } \\
\text { weatherstrip }\end{array}$ & 0.19 & 48 & 5472 & 28 & 1.4 \\
\hline $\begin{array}{l}\text {-air breathing } \\
\text { equipment }\end{array}$ & & & & & 55.9 \\
\hline -stack effect & & & & & 65.9 \\
\hline Internal lieat Load & & & & & $=93.2$ \\
\hline Unit demand & & & & & 303.9 \\
\hline
\end{tabular}


Structure Category

Transmission Heat Losses

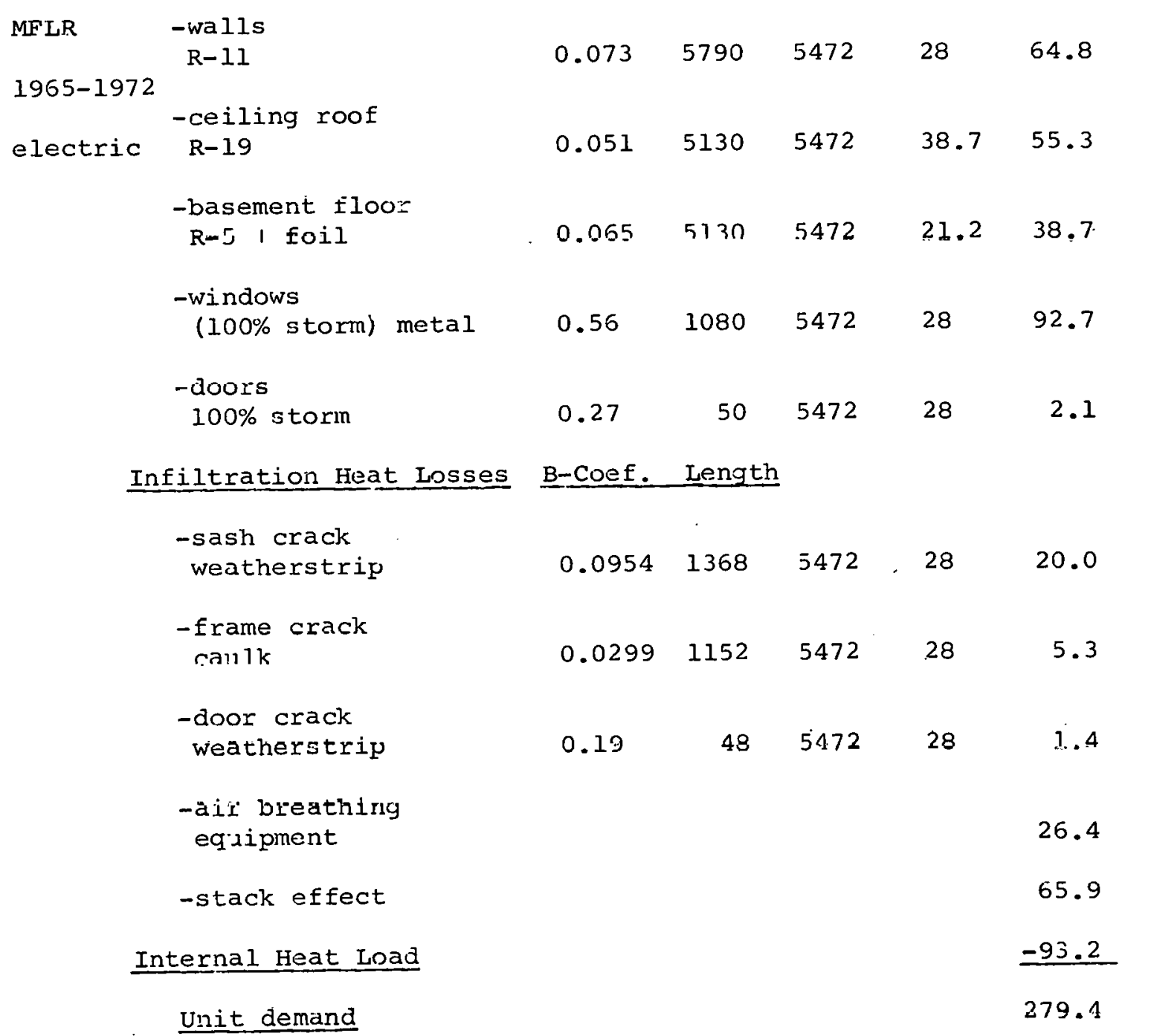




$$
\begin{gathered}
\text { MFLR } \quad \text { walls } \\
\text { R-ll }
\end{gathered}
$$

1965-1972

fossil

- ceiling roof
R-19

-basement floor

Foil

-windows

75\% storm (metal)

-doors

$75 \%$ storm

Infiltration Heat Losse

-sash crack

$50 \%$ weatherstrip

-frame crack caulk

- door crack

$50 \%$ weatherstrip

-air breathing

equipment

-stack effect

Internal Heat Load

Unit demand

$$
\begin{array}{lllll}
0.073 & 5790 & 5472 & 28 & 64.8
\end{array}
$$$$
\begin{array}{lllll}
0.051 & 5130 & 5472 & 38.7 & 55.3
\end{array}
$$$$
\begin{array}{lllll}
0.090 & 5130 & 5472 & 19.5 & 49.3
\end{array}
$$$$
\begin{array}{lllll}
0.702 & 1080 & 5472 & 28 & 116.2
\end{array}
$$

$\begin{array}{lllll}0.31 & 50 & 5472 & 28 & 2.4\end{array}$

B-Coef. Length

$\begin{array}{lrrrr}0.13 & 1368 & 5472 & 28 & 27.2 \\ 0.0299 & 1152 & 5472 & 28 & 5.3 \\ 0.259 & 48 & 5472 & 28 & 1.9 \\ & & & & 58.2 \\ & & & 65.9 \\ & & & -93.2 \\ & & & 353.3\end{array}$




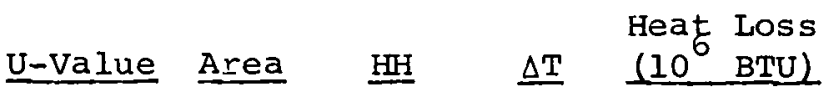

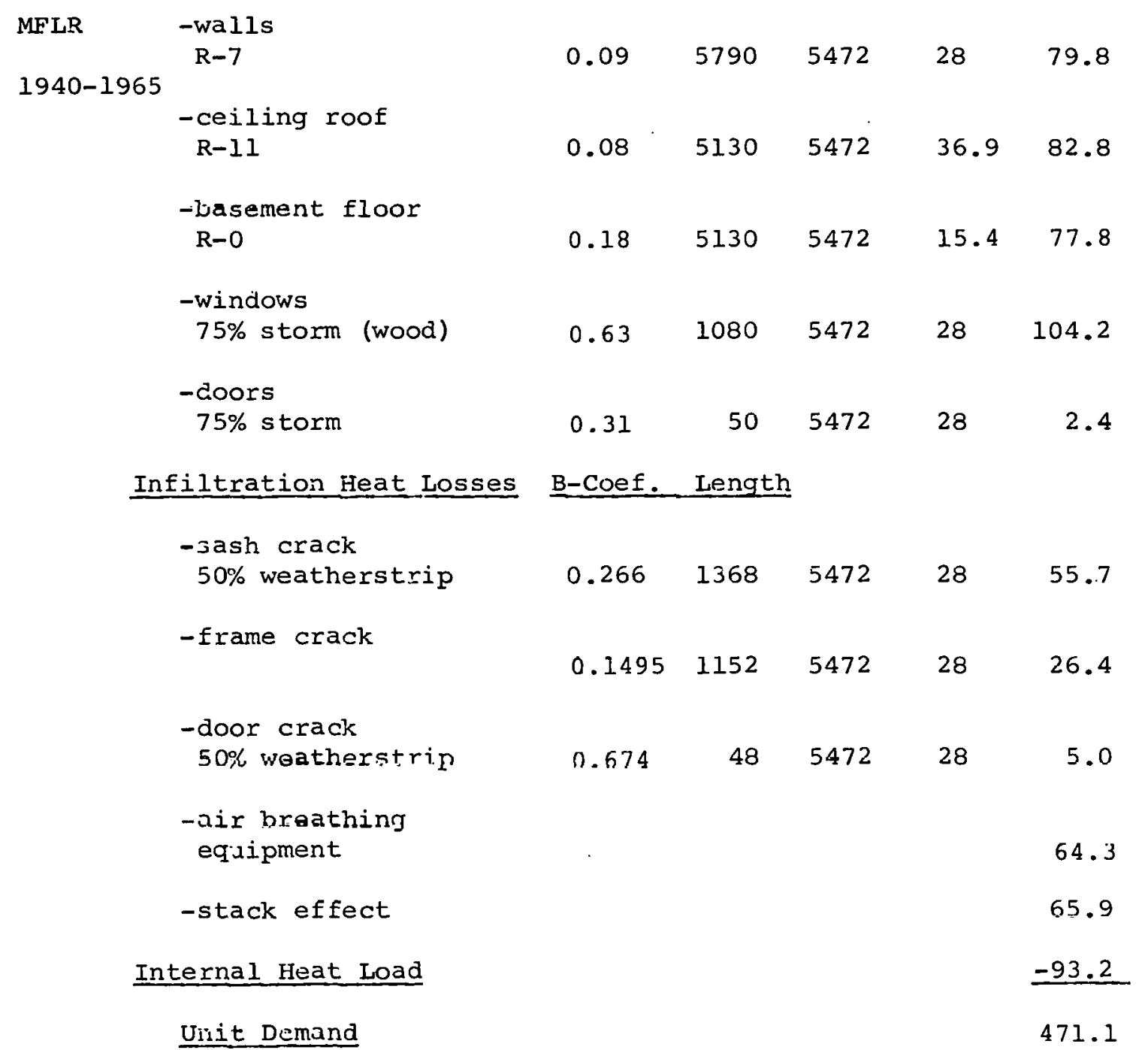

Uiitt Demand

471.1 
Structure

Categor

Transmission Heat Losses

U-Value Area

$\underline{\mathrm{HH}}$

Heat Loss

MFLR -walls

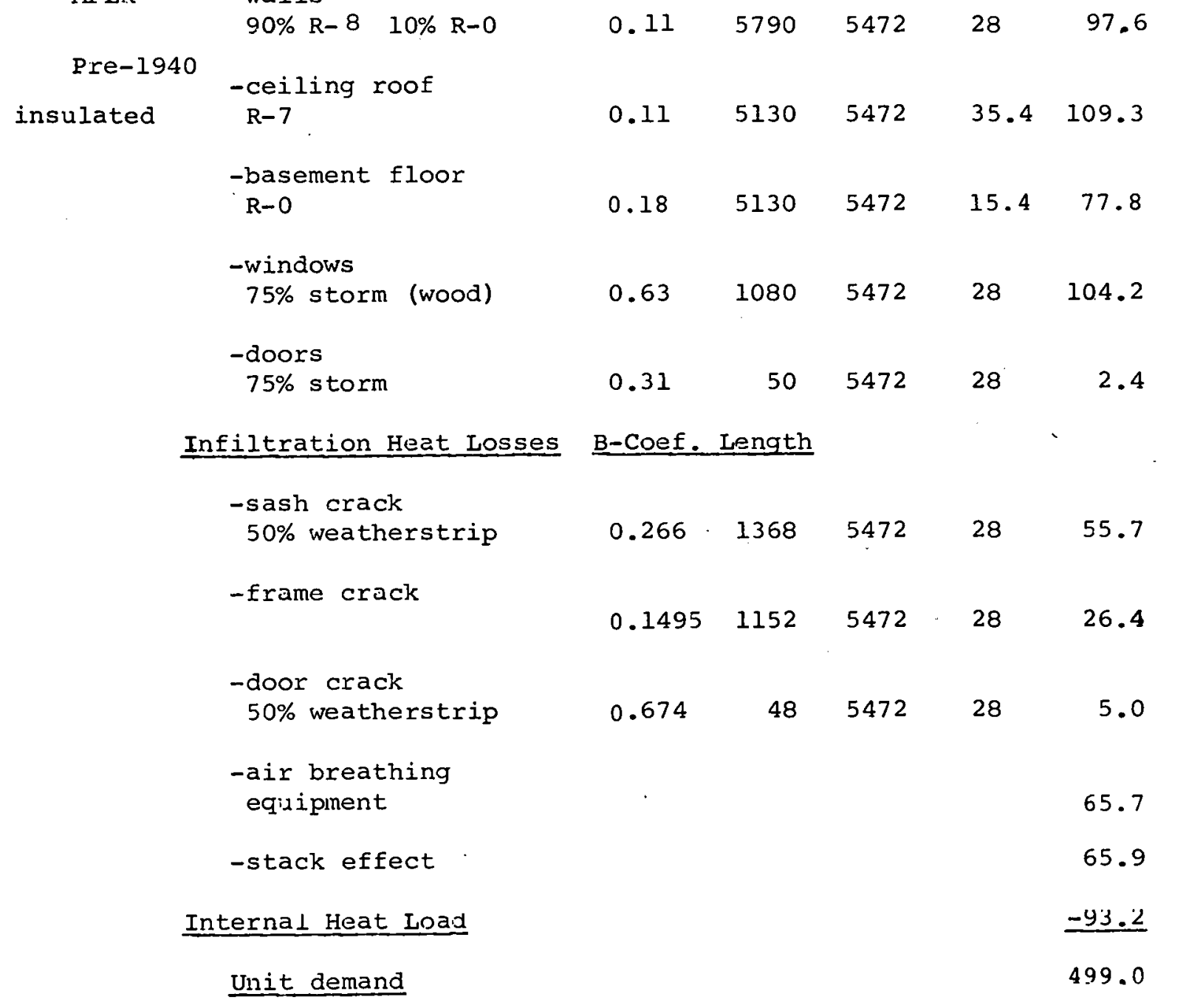

Unit demand 
Structure

Category

$$
\begin{array}{lc}
\text { MFLR } & \text {-walls } \\
\text { Pre-i940 } & \text { R-0 }
\end{array}
$$

-ceiling roof
uninsulated

-basement floor

$\mathrm{R}-\mathrm{O}$

-windows

$75 \%$ storm (wood)

-doors

$75 \%$ storm $\underline{\text { U-Value Area }}$

0.26

5790

0.34

5130

0.18

5130

5472

15.4

$\begin{array}{lllll}0.63 & 1080 & 5472 & 28 & 104.2\end{array}$

0.31

50

5472

28

2.4

Infiltration Heat Losses

-sash crack

$50 \%$ weatherstrip

-frame crack

-door. crack

$50 \%$ weatherstrip

-air breathing

equipment

-stack effect

Internal Heat Load

Unit demand
B-Coef. Length

$\begin{array}{lllll}.1495 & 1152 & 5472 & 28 & 26.4\end{array}$

$\begin{array}{lllll}.674 & 48 & 5472 & 28 & 5.0\end{array}$

82.0

65.9

$-93.2$

811.0

$\begin{array}{lllll}.266 & 1368 & 5472 & 28 & 55.7\end{array}$


Structure

Category
Transmission Heat Losses
U-Value Area

$$
\text { -walls }
$$

Masonry-insulated

1972-1985

-ceiling roof

electric flat deck (2.5" insulation)

-basement floor

Heated

-windows

100\% storm (metal)

-doors

solid wood

vestibule $\sim$ storm

Infiltration Heat Losses

-sash crack

-frame crack

caulk

-door crack solid wood

storm

-air breathing

equi.pment

-stack effect

Internal Heat Load

Unit Demand

B-Coef. Leng.th $\begin{array}{lllll}.12 & 25540 & 5472 & 28 & 469.6\end{array}$

$\begin{array}{lllll}.11 & 6384 & 5472 & 28 & 107.6\end{array}$

163.6

$\begin{array}{lllll}.56 & 6400 & 5472 & 28 & 549.1\end{array}$

$\begin{array}{lllll}.43 & 20 & 5472 & 28 & 1.3\end{array}$

$\begin{array}{lllll}.27 & 40 & 5472 & 28 & 1.7\end{array}$

$\begin{array}{lllll}.1015 & 8107 & 5472 & 28 & 126.1\end{array}$

$\begin{array}{lllll}.0299 & 6827 & 5472 & 28 & 31.3\end{array}$

$\begin{array}{lllll}.418 & 19 & 5472 & 28 & 1.2\end{array}$

$\begin{array}{lllll}.293 & 26 & 5472 & 28 & 1.2\end{array}$

95.1

410.2

$-580.0$

1378.0 
Structure

Category

Transmission Heat Losses

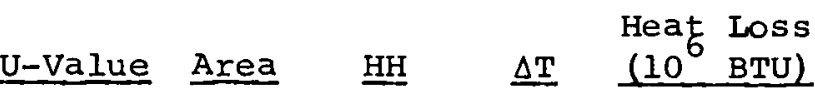

MFHR

-walls

R-5 masonry

$.12 \quad 25.540$

5472.28

469.6

1972-1985

-ceiling roof

fossil Flat deck (2.5"

insulation)

$.11 \quad 6384$

$5472 \quad 28$

107.6

-basement floor

Heated

163.6

-windows

$50 \%$ storm (metal)

.8456400

$5472 \quad 28$

828.6

-doors

solid wood

vestibule $\sim$ storm

$.43 \quad 20$

$5472 \quad 28$

1.3

$.27 \quad 40$

$5472 \quad 28$

1.7

Infiltration Heat Losses B-Coef. Length

-sash crack

$$
.17758107
$$

$5472 \quad 28$

220.5

-frame crack

caulk

0.02996827

547

28

31.3

-door crack

solid wood

storm

$.418 \quad 19$

5472

5472

1.2

.293

26

28

1.2

-air breathing

equipment

218.1

-stack effect

410.2

$-580.0$

Internal Heat Load

1874.9

Unit Demand 
Structure

Category Transmission Heat Losses

U-Value Area

HH $\quad \underline{\Delta T \quad \begin{array}{l}\text { Heat Loss } \\ \left(10^{6} \text { BTU }\right)\end{array}}$

\begin{tabular}{|c|c|c|c|c|c|c|}
\hline MFHR & $\begin{array}{l}\text {-walls } \\
\mathrm{R}-5 \text { mason } r y\end{array}$ & .12 & 25,540 & 5472 & 28 & 469.6 \\
\hline Pre-1972 & & & & & & \\
\hline & -ceiling roof & & & & & \\
\hline electric & Flat deck (2.5" & & & & & \\
\hline & insulation) & .11 & 6384 & 5472 & 28 & 107.6 \\
\hline & $\begin{array}{l}\text {-basement floor } \\
\text { heated }\end{array}$ & & & & & 163.6 \\
\hline . & -windows & & & & & \\
\hline & $50 \%$ storm (metal) & .845 & 6400 & 5472 & 28 & 828.6 \\
\hline & $\begin{array}{l}\text {-doors } \\
\text { solid wood }\end{array}$ & .43 & 20 & 5472 & 28 & 1.3 \\
\hline & vestibule $\sim$ s & .27 & 40 & 5472 & 28 & 1.7 \\
\hline
\end{tabular}

Infiltration Heat Losses B-coef. Length

\begin{tabular}{|c|c|c|c|c|c|}
\hline -sash crack & .1775 & 8107 & 5472 & 28 & 220.5 \\
\hline $\begin{array}{l}\text {-frame crack } \\
\text { caulk }\end{array}$ & 0.0299 & 6827 & 5472 & 28 & 31.3 \\
\hline $\begin{array}{l}\text {-door crack } \\
\text { solid wood } \\
\text { storm }\end{array}$ & $\begin{array}{l}.418 \\
. .293\end{array}$ & $\begin{array}{l}19 \\
26\end{array}$ & $\begin{array}{l}5472 \\
5472\end{array}$ & $\begin{array}{l}28 \\
28\end{array}$ & $\begin{array}{l}1.2 \\
1.2\end{array}$ \\
\hline $\begin{array}{l}\text {-air breathing } \\
\text { equipment }\end{array}$ & & & & & 95.1 \\
\hline -stack effect & & & & & 410.2 \\
\hline Internal Heat Load & & & & & -580.0 \\
\hline
\end{tabular}


Structure

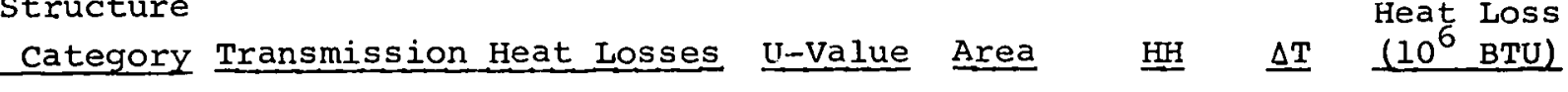

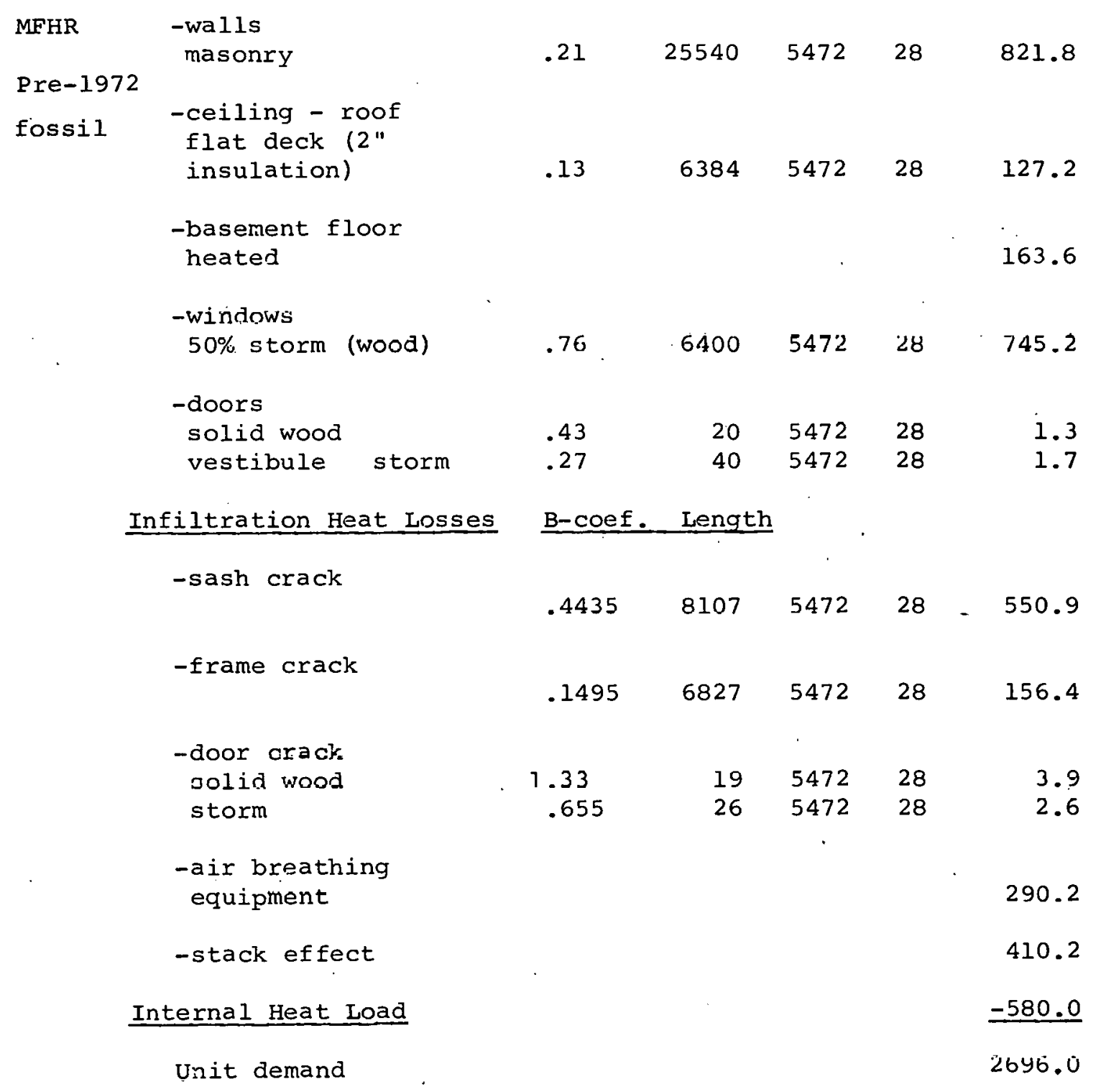




\section{Structure}

Category

Transmission Heat Losses

U-Value Area $\quad \underline{H} \quad \Delta \mathrm{T} \quad \begin{array}{r}\text { Heat Loss } \\ \left(10^{6} \text { BTU }\right)\end{array}$

Mobile -walls

electric

$\begin{array}{lllll}.12 & 902 & 5472 & 28 & 16.6\end{array}$

-ceiling-roof

$\begin{array}{lllll}.074 & 720 & -5472 & 28 & 8.2\end{array}$

-basement floor

$\begin{array}{lllll}.073 & 720 & 5472 & 28 & 8.1\end{array}$

-windows

metal

$\begin{array}{lllll}1.13 & 86 & 5472 & 28 & 14.9\end{array}$

-doors

solid wood

$\begin{array}{lllll}.43 & 20 & 5472 & 28 & 1.3\end{array}$

Infiltration Heat Losses B-coef. Length

-sash crack

$\begin{array}{lrrrr}.209 & 108 & 5472 & 28 & 3.5 \\ .1495 & 92 & 5472 & 28 & 2.1 \\ .874 & 19 & 5472 & 28 & 2.5 \\ & & & & \\ & & & & 1.9\end{array}$

-stack effect

Internal Heat Load

$-6.5$

Unit demand

52.6 

$\begin{array}{r}\text { Structure } \\ \text { Category } \\ \hline\end{array}$

Transmission Heat Losses

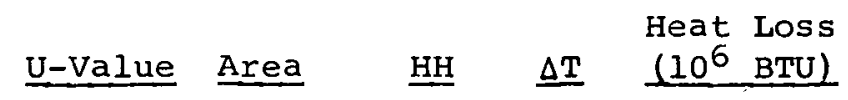

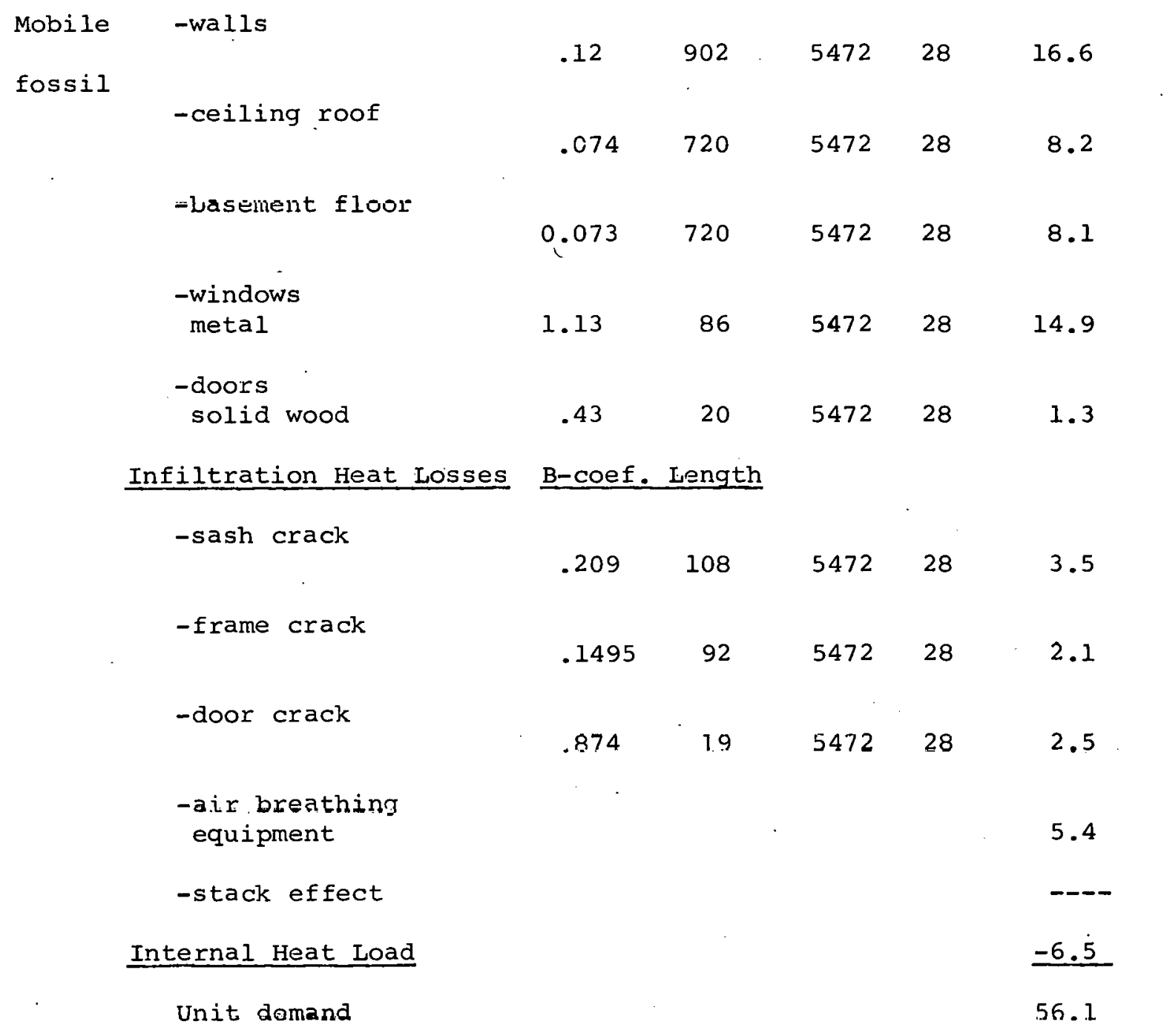


Appendix 5

Cooling Requirements of Prototypical

Building Structures 


$\begin{array}{ll}\text { SFD } & \begin{array}{l}\text {-walls } \\ \text { R-1l }\end{array} \\ 1972-1985 & \text {-ceiling roof } \\ \text { electric } & \text { R-24 } \\ & \text {-windinws } \\ & \\ & \\ & \text {-doors }\end{array}$

$\begin{array}{ccccc}\text { U-Value } & \text { Area } & \underline{\mathrm{CH}} & \underline{\Delta T} & \begin{array}{c}\text { Heat Gain } \\ \left(10^{6} \mathrm{BTU}\right)\end{array} \\ 0.073 & 1806 & 400 & 18.6 & .98 \\ 0.041 & 805 & 400 & 27.5 & .37 \\ \ddots & 242 & 400 & & 2.95 \\ 0.42 & 40 & 400 & 18.6 & .12\end{array}$

Infiltration Heat Gain y.1.1

$\begin{array}{llc}2088 \quad 400 & .92 \\ & \Sigma= & 5.34 \\ \text { Component load } & \frac{x 1.105}{5.90} \\ \text { Hinternal hcat load } & \frac{1.13}{10.33} \\ \text { Unit demand } & \end{array}$




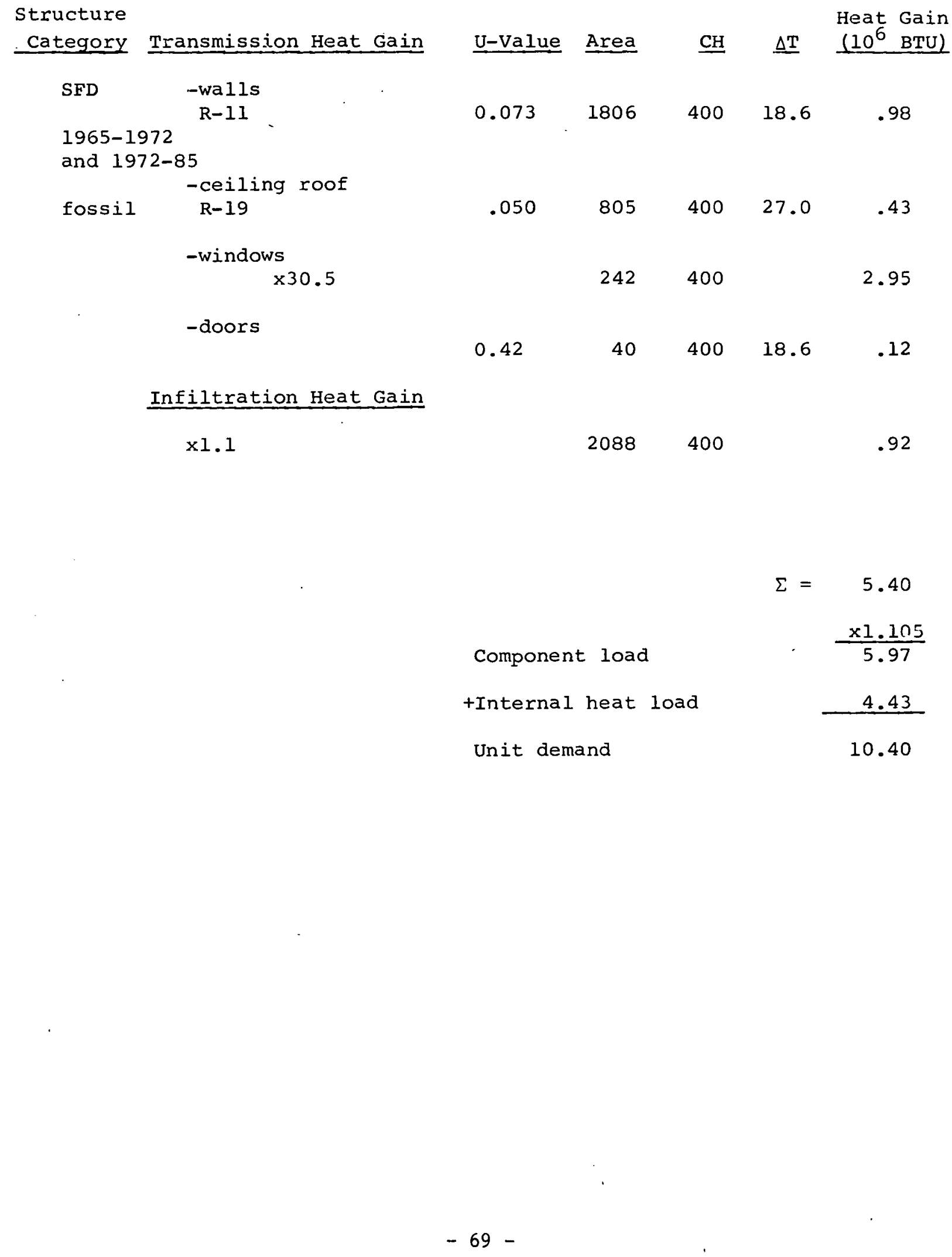


Structure

Category Transmission Heat Gain

$$
\begin{array}{ll}
\text { SFD } & \begin{array}{l}
\text {-walls } \\
\text { R-7 }
\end{array} \\
\text { 1940-1965 } & \\
& \text {-ceiling roof } \\
& \text { R-1l } \\
& \text {-windows } \\
& \times 30.5 \\
& \text {-doors }
\end{array}
$$

\begin{tabular}{|c|c|c|c|c|}
\hline U-Value & Area & CH & $\underline{\Delta T}$ & $\begin{array}{l}\text { leat } \mathrm{G} \\
110^{6} \mathrm{~B}\end{array}$ \\
\hline 0.09 & 1676 & 400 & 18.6 & 1.12 \\
\hline \multirow[t]{2}{*}{0.076} & 651 & 400 & 25.9 & 0.52 \\
\hline & 156 & 400 & & 1.90 \\
\hline .42 & 40 & 400 & 18.6 & .12 \\
\hline
\end{tabular}

\section{Infiltration Heat Gain}

x1.1
1872

400

.82

$$
\begin{array}{r}
\Sigma=\quad 4.48 \\
\frac{\times 1.105}{4.95} \\
\frac{3.58}{8.53}
\end{array}
$$




$\begin{array}{cc}\text { SFD } & \text {-walls } \\ \text { Pre-1940 } & 90 \% \mathrm{R}-8 \quad 10 \% \mathrm{R}-0 \\ \text { insulated } & \text {-ceiling roof } \\ & \mathrm{R}-7 \\ & \text {-windows } \\ & \times 30.5 \\ & \text {-doors } \\ & \\ & \text { Infiltration Heat Gain }\end{array}$

$\times 1.1$

$\begin{array}{lcc}1800 \quad 400 & .79 \\ & \Sigma= & 4.59 \\ & \frac{x 1.105}{5.07} \\ \text { Compenent Load } & 3.30 \\ \text { +Internal heat load } & 8.37 \\ \text { Unit Demand } & \end{array}$


Structure

Category Transmission Heat Gain

SFD -walls

R-O

Pre-1940

uninsulated
R-0

-windóws $\times 30.5$

-docrs

Infiltration Heat Gain

x1.1

$\begin{array}{ccccc}\text { U-Value } & \text { Area } & \underline{\mathrm{CH}} & \underline{\Delta \mathrm{T}} & \begin{array}{c}\text { Heat Gain } \\ \left(10^{6} \mathrm{BTU}\right)\end{array} \\ .28 & 1616 & 400 & 18.6 & 3.01 \\ & 600 & 400 & 19.3 & 1.31 \\ .42 & 144 & 400 & & 1.76 \\ & 40 & 400 & 18.6 & .12\end{array}$

1800

400 .79

$\Sigma=5.99$
$\frac{\times 1.105}{6.29}$

9.3 .30
9.59




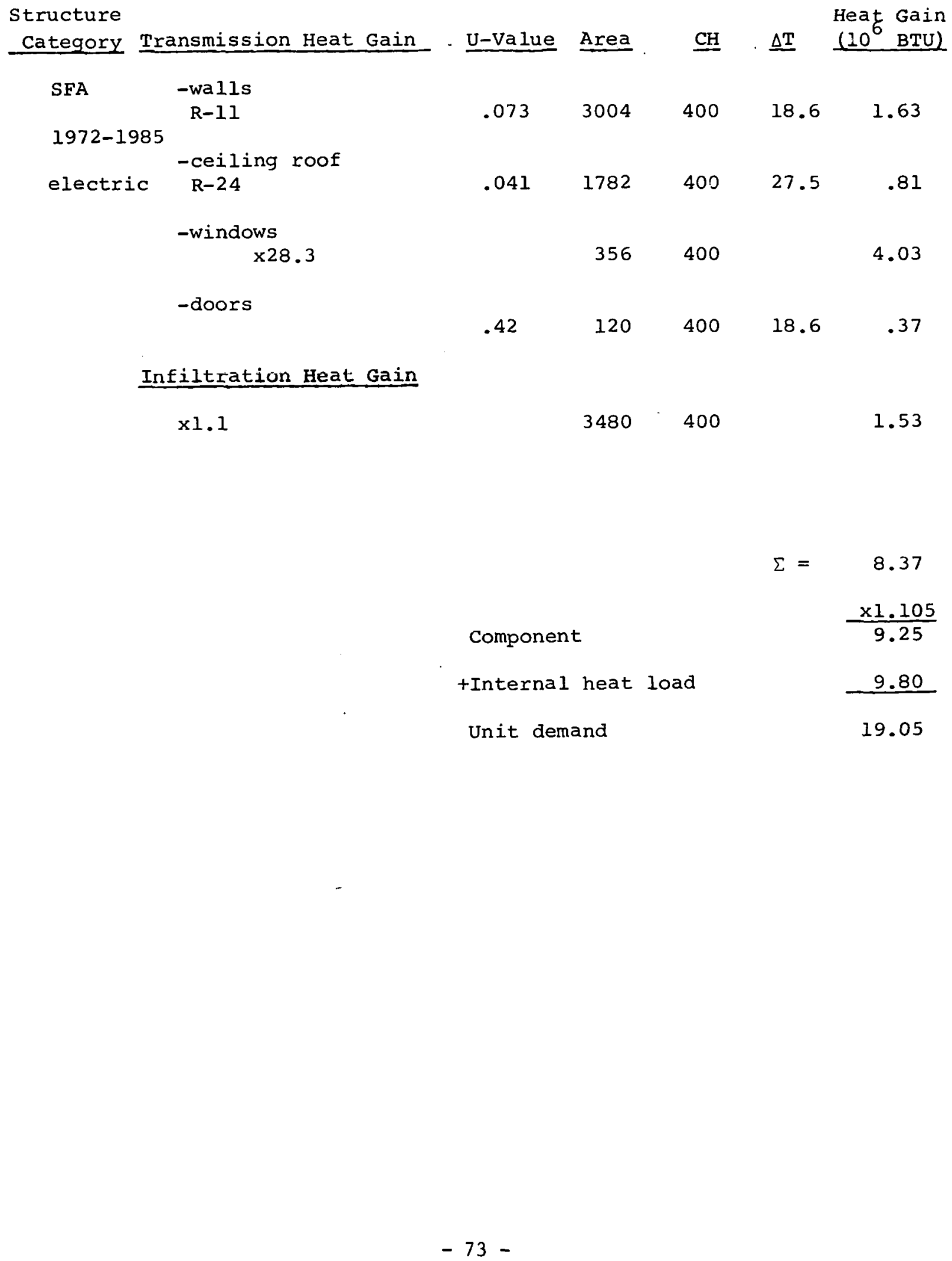




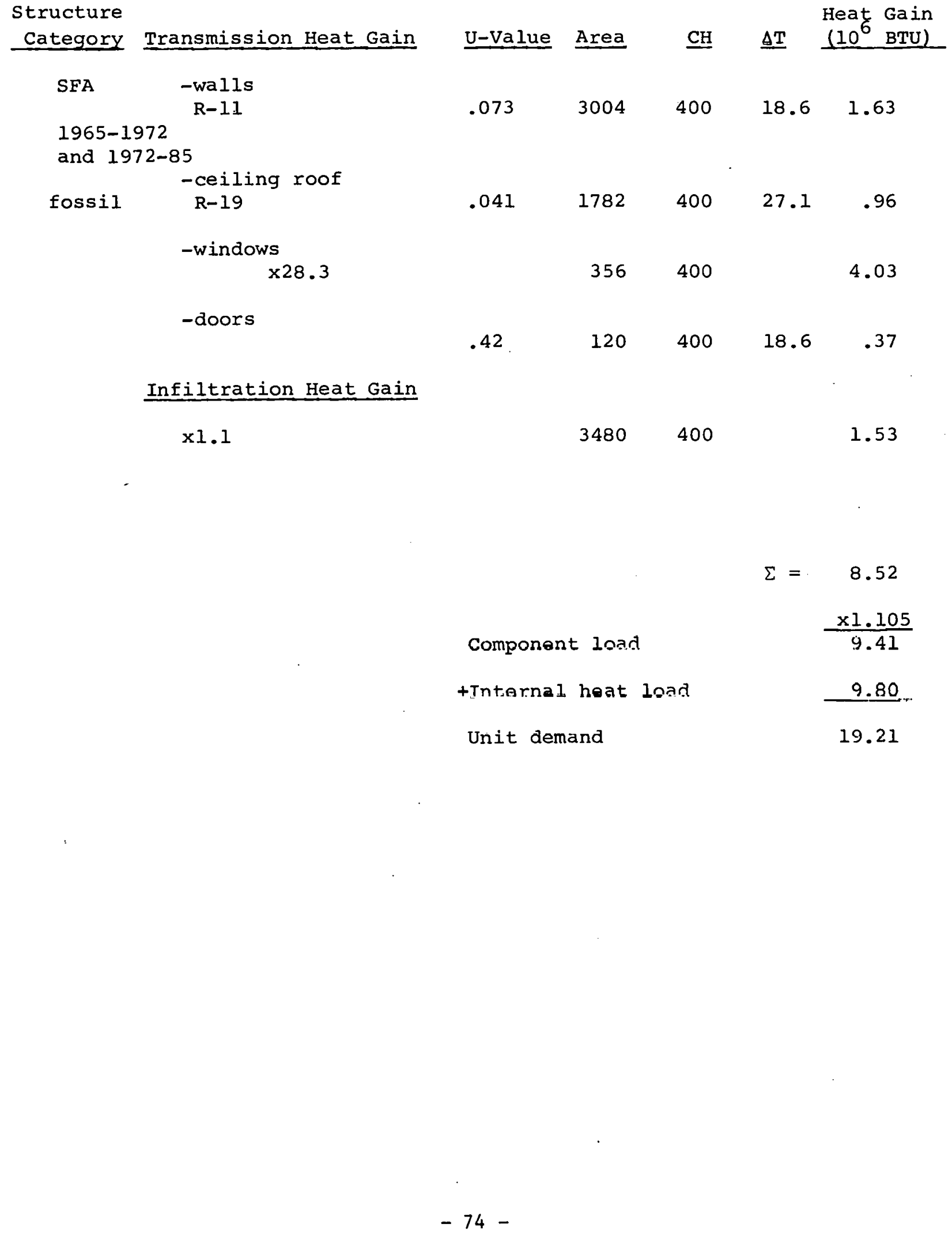




$$
\text { SFA }
$$

-doors

\section{Infiltration Heat Gain}

$\mathrm{x} 1.1$

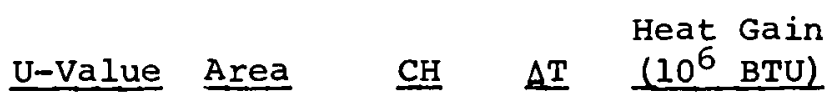

$\begin{array}{lllll}0.09 & 2874 & 400 & 18.6 & 1.92\end{array}$

$\begin{array}{lllll}0.076 & 1632 & 400 & 25.9 & 1.28\end{array}$

$326 \quad 400 \quad 3.69$

$\begin{array}{lllll}.42 & 40 & 400 & 18.6 & .37\end{array}$

$\Sigma=\quad 8.72$
$\frac{\times 1.105}{9.64}$
8.97
18.61

\author{
Component load \\ +Internal heat load \\ Unit demand
}

$$
1.46
$$

400

18.61 


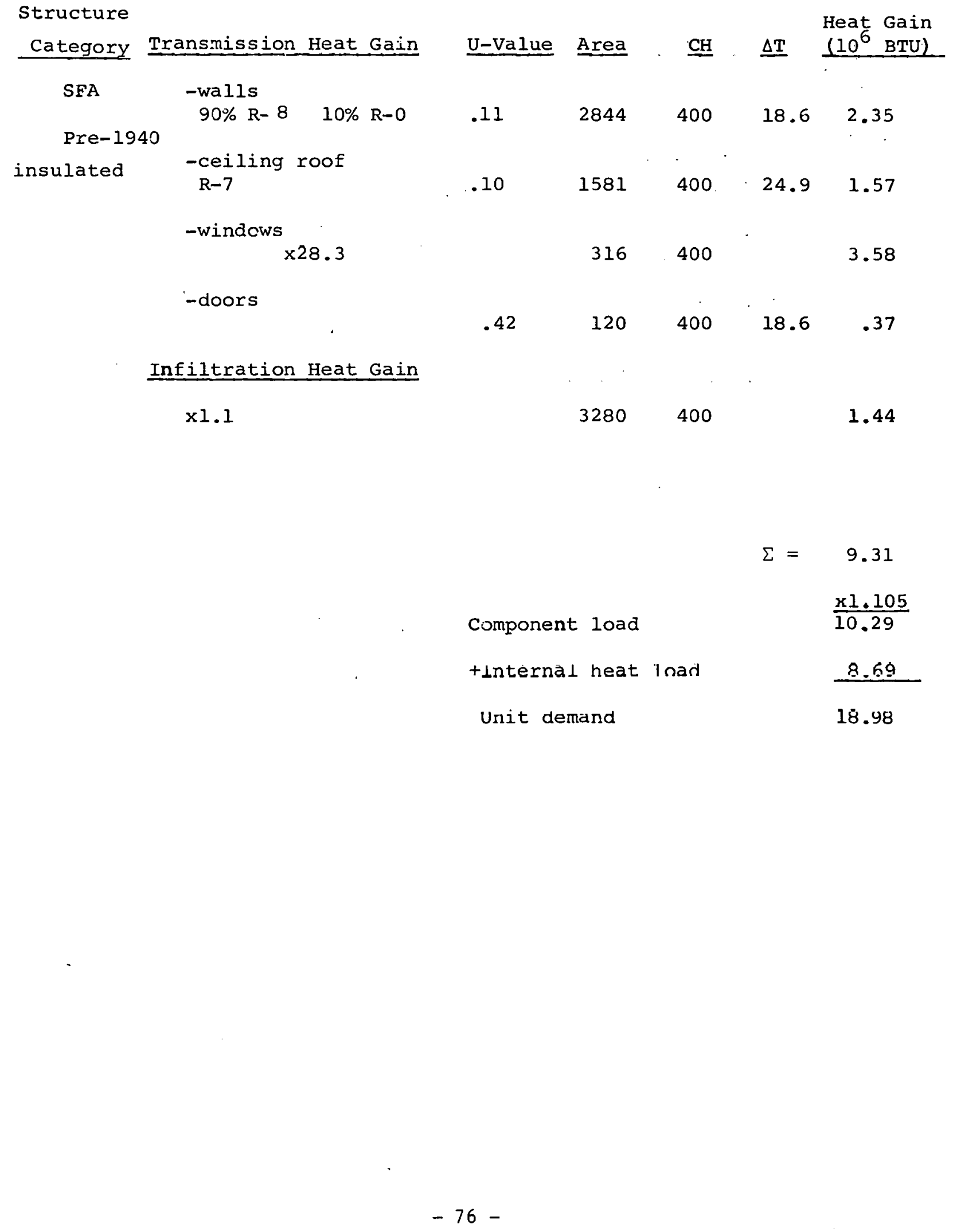


Structure

Category Transmission Heat Gain

SFA

$$
\begin{aligned}
& - \text { walls } \\
& \text { R-0 }
\end{aligned}
$$

Pre -1940

-ceiling roof

uninsulated $\quad R-0$

-windows

$\times 28.3$

-doors

Infiltration Heat Gain

$\times 1.1$

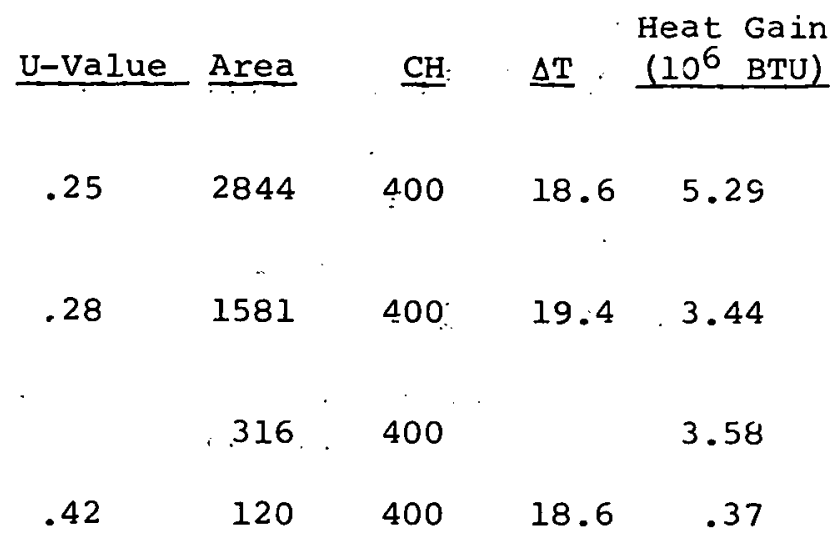

$3280 \quad 400$

1.44 
Structure

Category Transmission Heat Gain

$\begin{array}{ll}\text { MFLR } & \begin{array}{c}\text {-walls } \\ \text { R-1l }\end{array} \\ 1972-1985 & \text {-ceiling roof } \\ \text { electric } & \text { R-24 } \\ & \text {-windows } \\ & \times 23.05 \\ & \\ & \text {-doors }\end{array}$

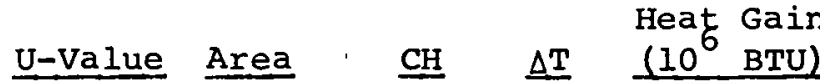

$\begin{array}{lllll}.073 & 5790 \quad 400 & 18.6 & 3.14\end{array}$

$\begin{array}{lllll}0.041 & 5130 & 400 & 27.9 & 2.35\end{array}$

$1080 \quad 400 \quad 9.96$

.42

$\begin{array}{llll}50 & 400 \quad 18.6 \quad .16\end{array}$

Infiltration Heat Gain

$x 1,1$

6920

400

3.04

$\Sigma=18.65$
$\frac{\times 1.105}{20.61}$

$\frac{28.21}{48.82}$

Component load

+Internal heat load

48.82 
Structure

Category Transmission Heat Gain

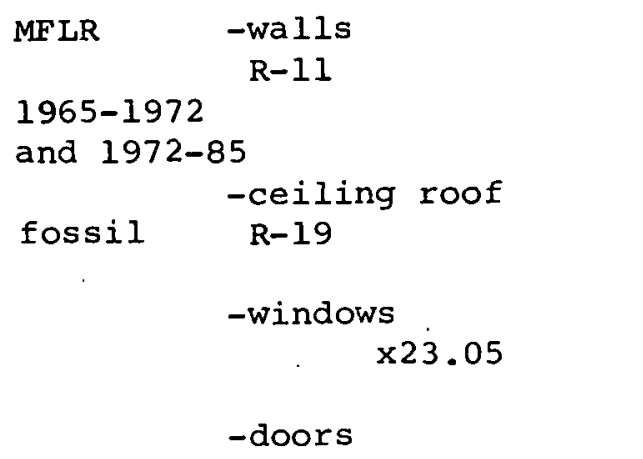

Infiltration Heat Gain

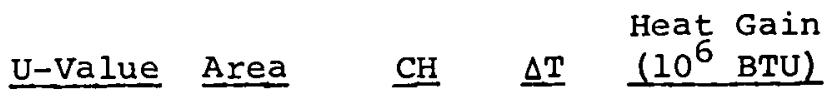

$\begin{array}{lllll}.073 & 5790 & 400 & 18.6 & 3.14\end{array}$

$\begin{array}{lllll}.050 & 5130 & 400 & 27.5 & 2.82\end{array}$

1080

400

9.96

.42

50

400

18.6

.16

xl.1

$6920 \quad 400$

\author{
Component load \\ +Internal heat load \\ Unit demand
}
3.04

$\begin{aligned} \Sigma= & 19.12 \\ & \frac{\times 1.105}{21.13} \\ & \frac{28.21}{49.34}\end{aligned}$

: 


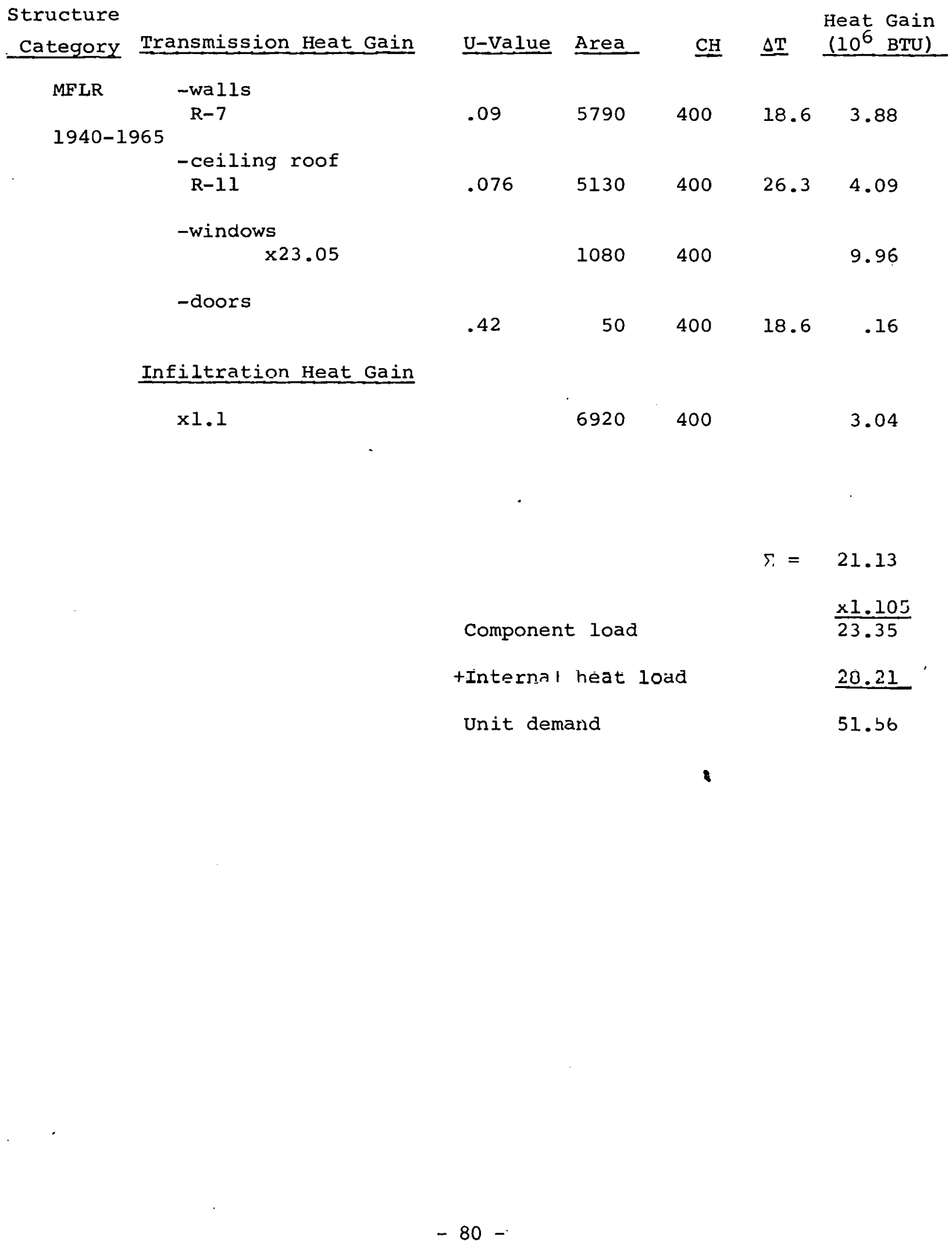




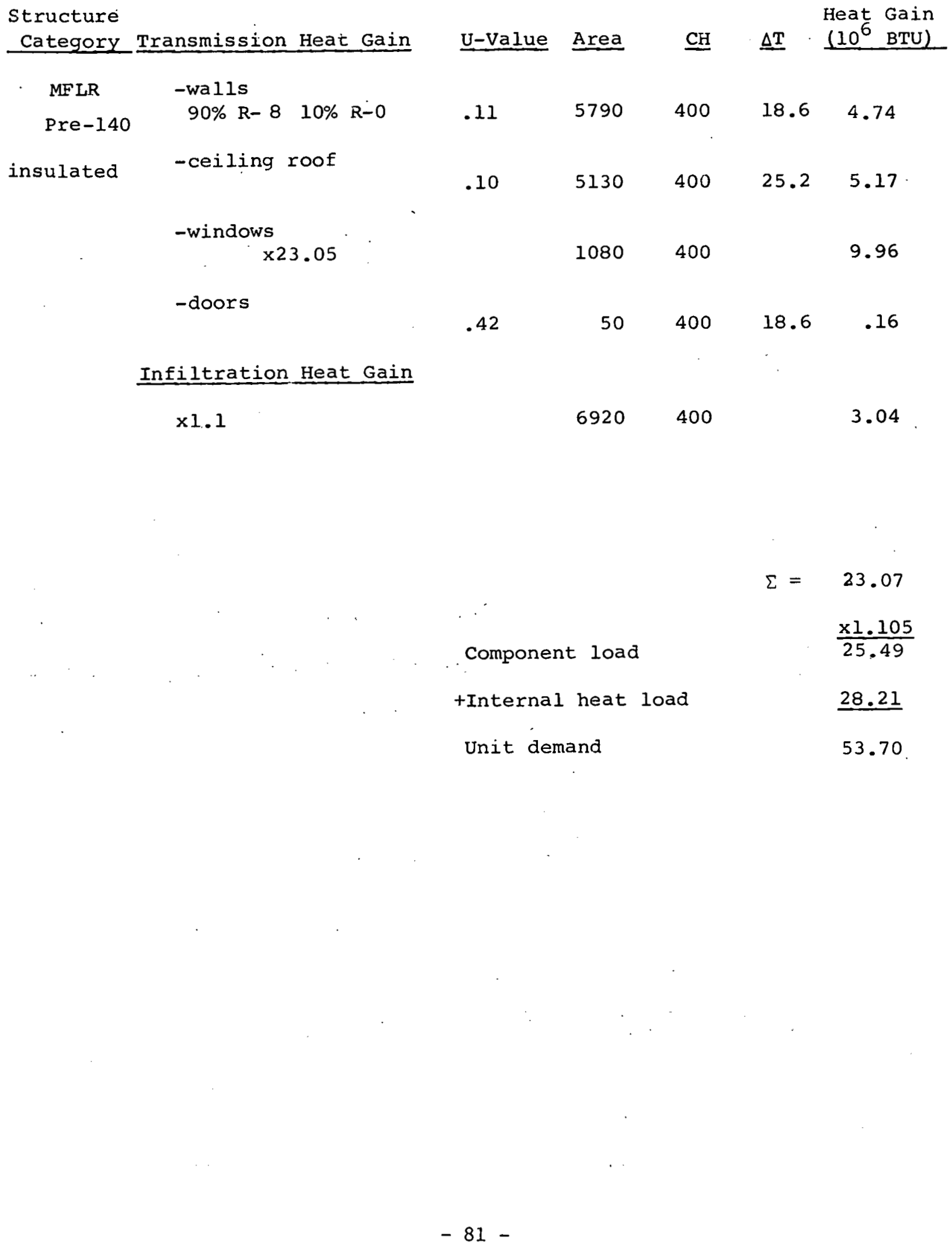


Structure

Category Transmission Heat Gain

$$
\text { MFLR -walls }
$$

Pre -1940

$$
\begin{array}{ll} 
& - \text { ceiling roof } \\
\text { uninsulated } & \text { R-0 }
\end{array}
$$

-windows

$$
\times 23.05
$$

\begin{tabular}{|c|c|c|c|c|}
\hline U-Value & Area & $\mathrm{CH}$ & $\underline{\Delta T}$ & $\begin{array}{l}\text { Jeat Gai } \\
\left(10^{\circ} \text { BTU }\right.\end{array}$ \\
\hline .25 & 5790 & 400 & 18.6 & 10.76 \\
\hline .28 & & 400 & 19.5 & 11.19 \\
\hline & 1080 & 400 & & 9.96 \\
\hline .42 & 50 & 400 & 18.6 & .16 \\
\hline
\end{tabular}

-doors

Infiltration Heat Gain

$$
x I .1
$$

$6920 \quad 400$ 3.04

$\Sigma=\quad 35.11$
$\frac{x 1.105}{38.80}$
$\frac{28.21}{67.01}$


Structure

Category Transmission Heat Gain

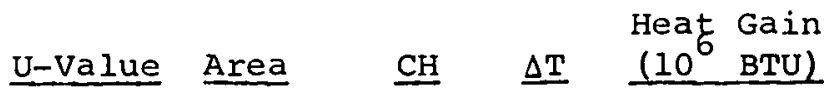

MFHR

-walls

1972-1985

masonry-insulated

.12

25540

400

18.6

22.80

and 1965-72

-ceiling roof

electric flat deck (2.5"

insulation)

$\begin{array}{lllll}.094 & 6384 & 400 & 35 & 8.40\end{array}$

-windows

$$
\times 27.2
$$

$6400 \quad 400$

69.63

-doors

.42

60

400

18.6

.19

Infiltration Heat Gain

$x 1.1$

$$
32,000
$$

400

14.08

$$
\begin{array}{r}
\Sigma=115.10 \\
\frac{\times 1.105}{127.19} \\
175.51 \\
302.70
\end{array}
$$$$
\text { Component load }
$$$$
\text { +Internal heat load }
$$$$
\text { Unit demand }
$$ 
Structure

Category Transmission Heat Gain

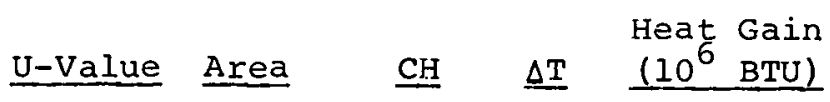

$\begin{array}{cl}\text { MFHR } & \begin{array}{c}\text {-walls } \\ \text { masonry }\end{array} \\ \text { Pre-1972 } & \text {-ceiling roof } \\ \text { fossil } & \begin{array}{l}\text { flat deck (2" } \\ \text { insulation) }\end{array} \\ & \text {-windows } \\ & \times 27.2 \\ & \text {-doors }\end{array}$

$\begin{array}{lllll}.21 & 25540 \quad 400 & 18.6 & 39.90\end{array}$

$\begin{array}{lllll}.11 & 6384 & 400 & 35 & 9.83\end{array}$

$\begin{array}{lll}6400 \quad 400 & 69.63\end{array}$

$\begin{array}{lllll}.42 & 60 & 400 & 18.6 & .19\end{array}$

Infiltration Heat Gain

$x 1.1$

$32,000 \quad 400 \quad 14.08$

Component load

$\Sigma=133.63$

$\times 1.105$

147.66

Hnternal heat load

175.51

Unit demand

323.17 
Structure

Category

Mobile

$x 1.1$

Transmission Heat Gain

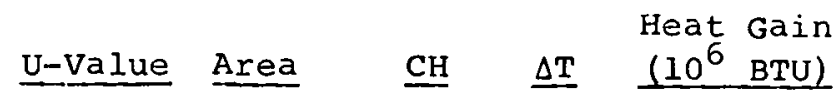

$\begin{array}{lllll}.11 & 902 & 400 & 18.6 & .74\end{array}$

-ceiling roof

$\begin{array}{lllll}.072 & 720 & 400 & 35 & .73\end{array}$

-windows

$\times 31.7$

86

400

1.07

-doors

.42

20

400

18.6

0.06

-floor (open

crawl space)

.076

720

400

10.0

.22

Infiltration Heat Gain

1008

400

0.49

Component load

$\Sigma=3.31$

$\frac{x 1.105}{3.66}$

+Internal heat load

1.98

Unit demand

5.64 
Appendix 6

New England's Inventory of Residential Housing, 
The basic accounting identity for projecting the 1972 housing stock to the year 1985 or 2000 is (Arthur D. Little, 1974) :

$$
\begin{aligned}
& \mathrm{HS}_{\text {te }}=\mathrm{HS}_{\mathrm{B}}+\mathrm{C}_{\mathrm{t}}-\mathrm{R}_{\mathrm{t}} \\
& \text { where } \mathrm{HS}_{\mathrm{te}}: \begin{array}{l}
\text { housing stock at the end of a projection } \\
\text { interval. }
\end{array} \\
& \mathrm{HS}_{\mathrm{B}}=\begin{array}{l}
\text { housing stock at the beginning of the pro- } \\
\text { jection interval. }
\end{array} \\
& \mathrm{C}_{t}=\begin{array}{l}
\text { number of new units constructed over the } \\
\mathrm{R}_{\mathrm{t}}= \\
\text { housing interval. }
\end{array}
\end{aligned}
$$

Two projection intervals are considered, 1972-1985 and 1985-2000.

All the buildings removed during the intervals are assumed to pre-date 1965.

\section{Residential Inventory}

and Age Structure (103 Housing Units) *

\section{Inventory}

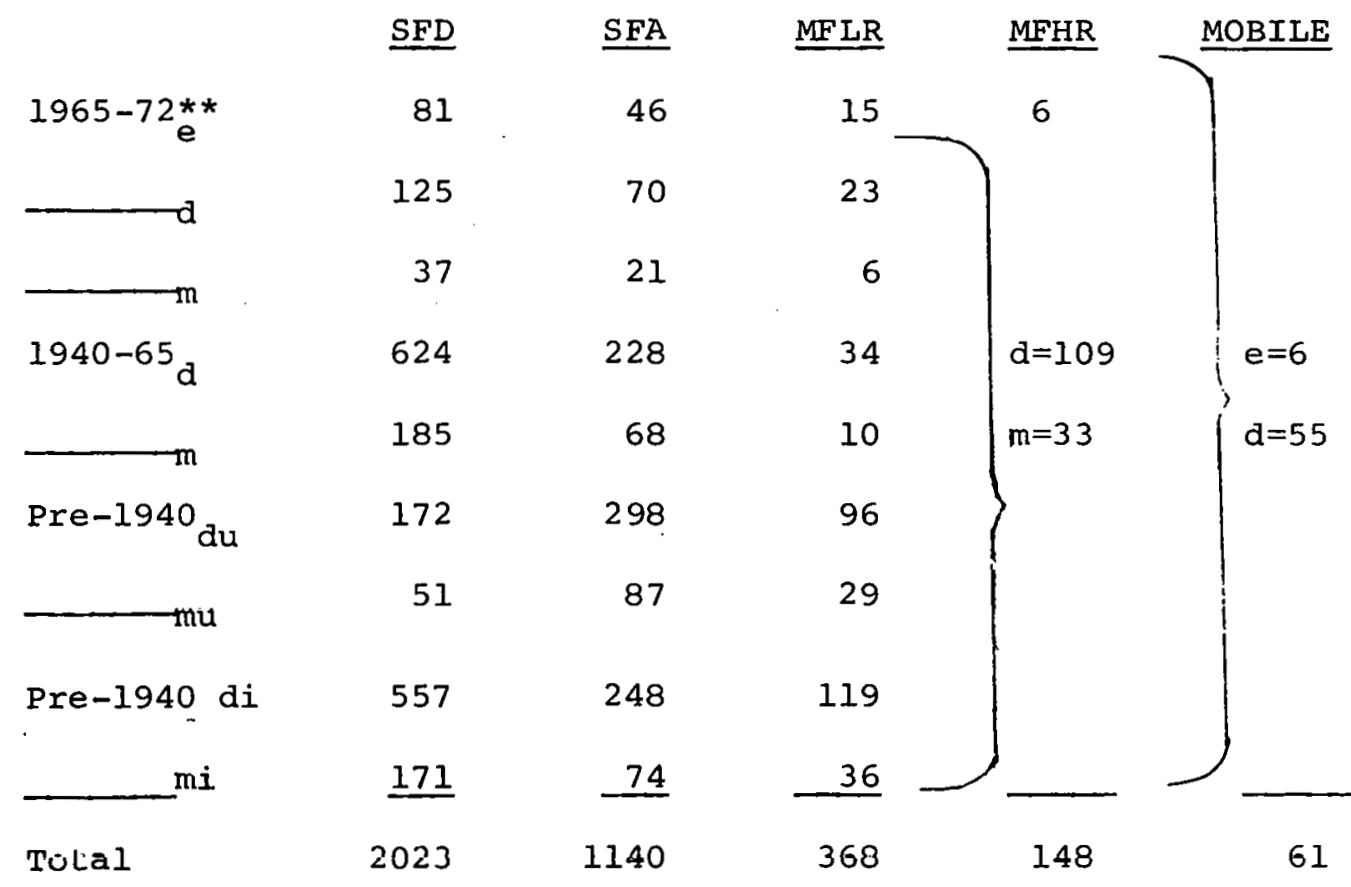

*Based on dee (1976) and Marcin (1972 and 1975).

**First subscript refers to fuel type; e: electricity, d: distillate, and $\mathrm{m}$ : methane. For pre-1940 housing and the second subscript refers to level of insulation; $i$ : insulated。 and $\mathrm{u}$ : uninsulated. 
1985 Inventory

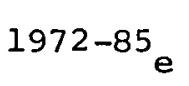

SFA $\underline{\text { MFLR }} \underline{\text { MFHR }} \underline{\text { MOBILE }}$

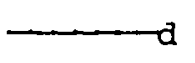

93

55

379

172

117

13

100

79

20

25

$1965-72$

$81 \quad 46$

$15 \quad 6$

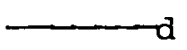

125

70

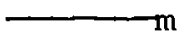

37

21

$1940-65 d$

546

154

162

46

$\longrightarrow \mathrm{m}$

162

Pre-1940 du

$151 \quad 201$

$\underbrace{\mathrm{mu}}$

45

59

mi

505

167

Pre-1940 di

150

50

llotal

2472

1158

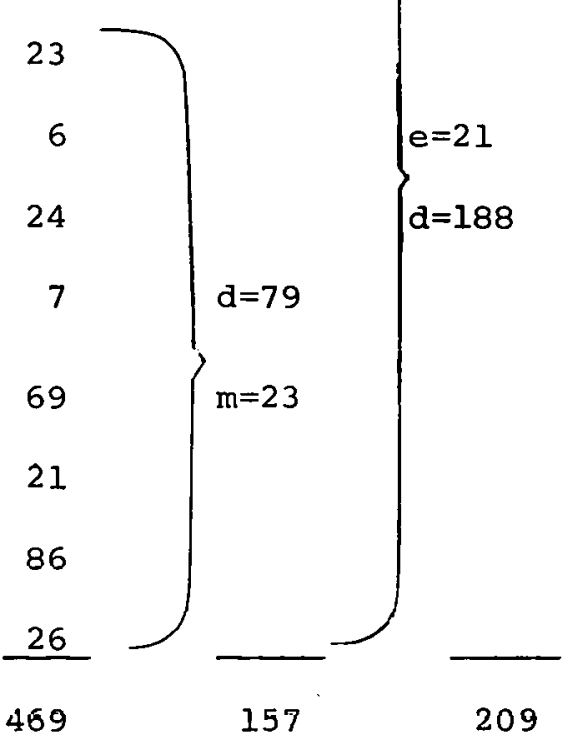


2000 Inventory

\begin{tabular}{|c|c|c|c|c|c|}
\hline & $\underline{\text { SFD }}$ & $\underline{\mathrm{SFA}}$ & MFLR & MFHR & MOBILE \\
\hline $1985-2000_{\mathrm{e}}$ & 527 & 184 & 108 & 26 & 20 \\
\hline$\longrightarrow \mathrm{d}$ & 456 & 200 & 94 & 29 & 180 \\
\hline & 57 & 36 & 30 & 5 & \\
\hline \multirow{3}{*}{$1972-85 \mathrm{e}$} & 191 & 93 & 55 & 13 & - \\
\hline & 379 & 172 & 117 & 25 & \\
\hline & 100 & 79 & 20 & 8 & \\
\hline \multirow{3}{*}{$1965-72 \mathrm{e}$} & 81 & 46 & 15 & 6 & \\
\hline & 125 & 70 & 23 & & \\
\hline & 37 & 21 & 6 & & $e=10$ \\
\hline \multirow[t]{2}{*}{$1940-65 \mathrm{~d}$} & 435 & 67 & 11 & & $d=86$ \\
\hline & 129 & 20 & 3 & $d=48$ & \\
\hline Pre-1940 du & 120 & 87 & 32 & $m=15$ & \\
\hline $\mathrm{mu}$ & 36 & 26 & 10 & & \\
\hline Pre-1940 di & 403 & 73 & 39 & & \\
\hline $\mathrm{mi}$ & 120 & 22 & 12 & & \\
\hline Total & 3106 & 1106 & 575 & 175 & 296 \\
\hline
\end{tabular}


The following parameters found in the fuel mix tables must be defined before the projections of energy demand and the fuel mix for the reference years are developed.

1. Unit basic demand, $\mathrm{E}$ : the heating or cooling requirements of an average unit for a given reference year (assuming $100 \%$ system efficiency)..

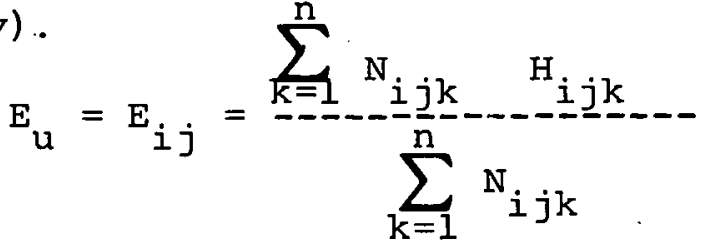

where: $\mathrm{N}=$ number of housing units $\mathrm{H}$ = heating or cooling requirements of a unit and subscripts: $i=$ fuel type

$j$ = structure category

$\mathrm{k}=$ age category of structure.

2. Saturation, $s$ : fraction of the potential demand for a particular energy use actually being fulfilled at a given time.

3. Fuel fraction, $f_{i}$ : fraction of the total number of energy consuming units (basis) that is satisfied by using the ith fuel.

4. Relative system efficiency, $e_{j}$ : the relative effectiveness with which fuel, $i$, is used in demand category.

5. Fuel demand $D_{i}$ : the quantity of a fuel, $i$, actually consumed in a specific demand category

$$
D_{i}=E_{i j} \times S \times \text { Basis } \times f_{i} \div e_{i} \text {. }
$$

6. Total fuel demand, $\mathrm{D}$ : The total fuel required to satisfy the requirements of a specific demand category

$$
\mathrm{D}=\sum_{i=1}^{\mathrm{m}} \mathrm{D}_{i}
$$




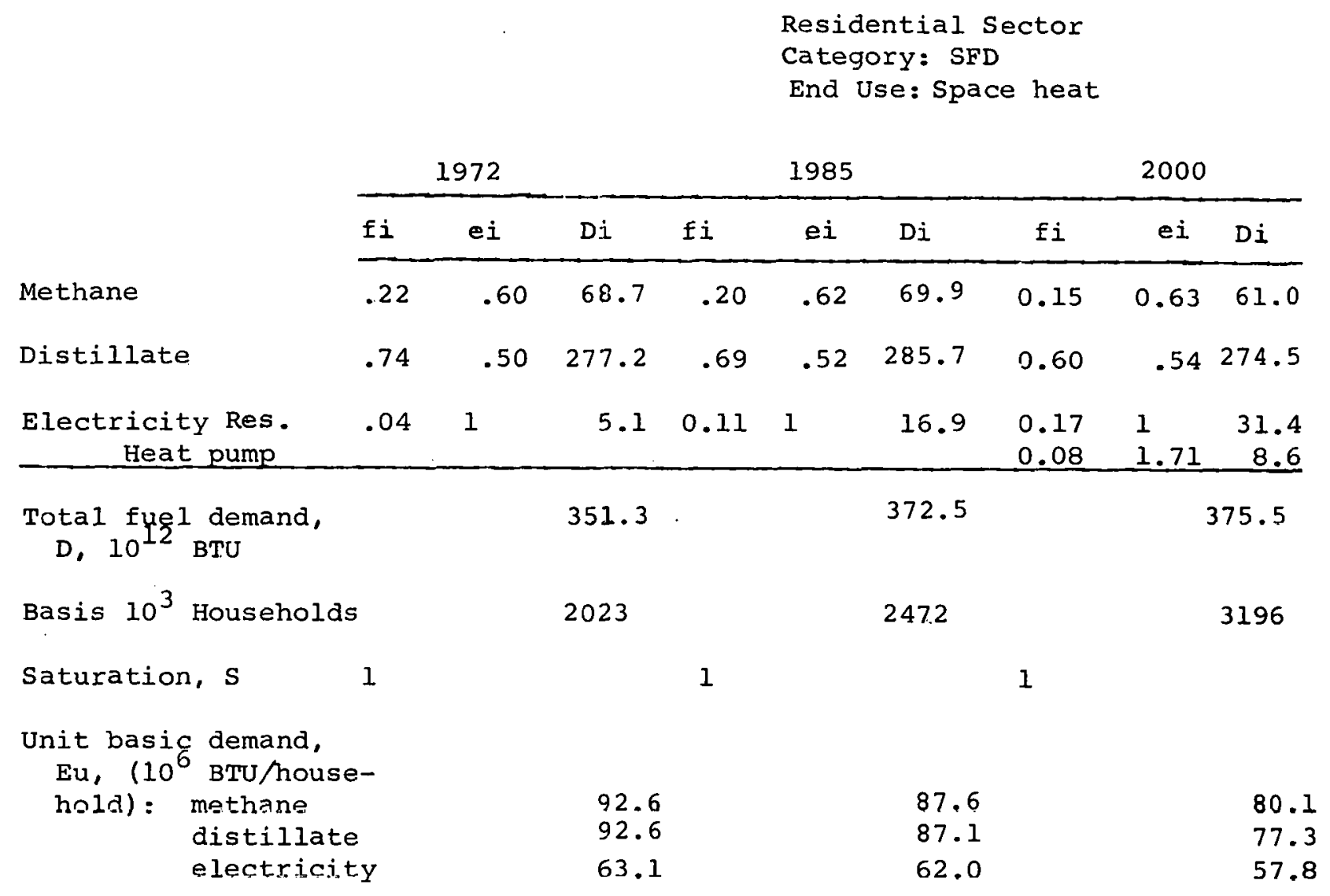


Residential Sector

Category: SFA

End Use: Space Heat

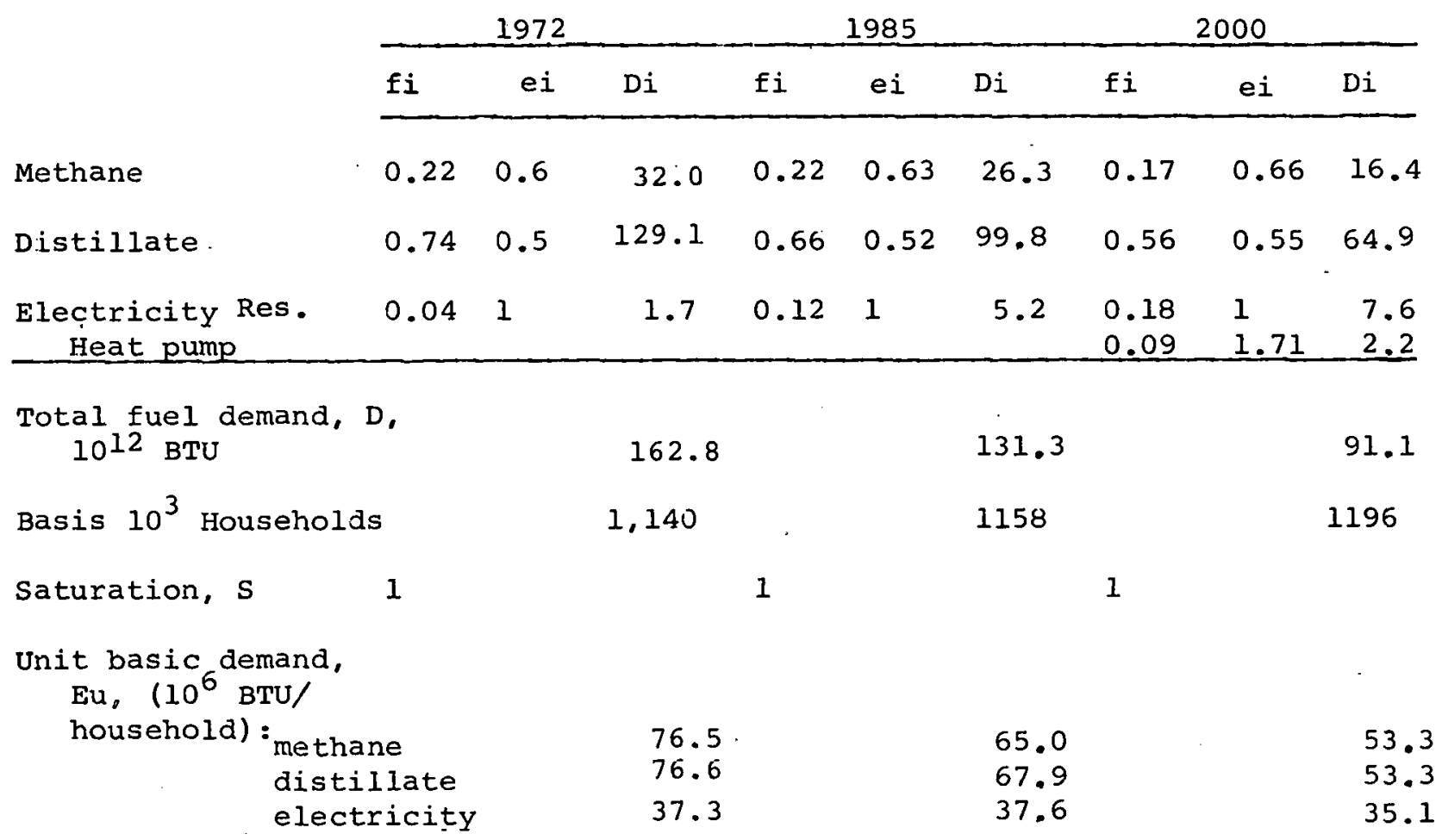


Residential Sector

Category: MFLR

End Use: Space Heat

\begin{tabular}{|c|c|c|c|c|c|c|c|c|c|}
\hline \multirow[b]{3}{*}{ Methane } & \multicolumn{3}{|c|}{1972} & \multicolumn{3}{|c|}{1985} & \multicolumn{3}{|c|}{2000} \\
\hline & $\mathrm{fi}$ & $e i$ & $\mathrm{Di}$ & $\mathrm{fi}$ & ei & $\mathrm{Di}$ & $f i$ & ei & $\mathrm{Di}$ \\
\hline & 0.22 & 0.6 & 8.0 & 0.17 & 0.63 & 6.6 & 0.14 & 0.66 & 4.7 \\
\hline Distillate & 0.74 & 0.5 & 32.3 & 0.68 & 0.54 & 8.6 & 0.55 & 0.57 & 20.6 \\
\hline $\begin{array}{l}\text { Electricity } \\
\text { Heat pump } \\
\end{array}$ & 0.04 & 1 & 0.4 & 0.15 & 1 & 1.9 & $\begin{array}{l}0.21 \\
0.10 \\
\end{array}$ & $\begin{array}{l}1 \\
1.71 \\
\end{array}$ & $\begin{array}{l}3.1 \\
0.9 \\
\end{array}$ \\
\hline $\begin{array}{c}\text { Total fuel demand, } \\
10^{12} \text { BTU }\end{array}$ & b, & - & 40.7 & & & 37.1 & & & 29.3 \\
\hline Basis $10^{3}$ Household & & & 388 & & & 469 & & & 575 \\
\hline Saturation, s & 1 & & & 1 & & & 1 & & \\
\hline 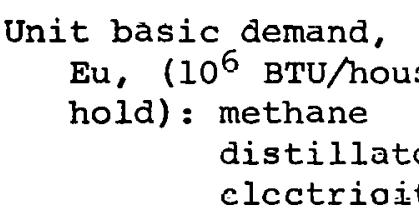 & & & $\begin{array}{l}59.3 \\
59.3 \\
27.0\end{array}$ & & & $\begin{array}{l}52.3 \\
48.4 \\
27.2\end{array}$ & & & $\begin{array}{l}38.7 \\
37.1 \\
25.4\end{array}$ \\
\hline
\end{tabular}


Residential Sector

Category: MFHR

End Use: Space Heat

\begin{tabular}{llllllllll}
\hline & 1972 & & \multicolumn{3}{c}{1985} & & & 2000 & \\
\hline fi & ei & Di & fi & ei & Di & fi & ei & Di \\
\hline
\end{tabular}

Methane

0.6

2.4

0.210 .63

2.1

0.16

$0.65 \quad 1.6$

Distillate

0.74

0.5

9.8

0.67

0.52

8.4

0.58

$0.55 \quad 6.5$

Electricity Res.

0.041

0.2

0.121

0.5

0.18

1

0.7

Heat pump

$.08 \quad 1.71 \quad 0.2$

Total fuel demand, $D$, $10^{12}$ BTU

12.4

12.0

9.0

Basis $10^{3}$ Households

148

157

175

saturation, s

1

1

1

Unit basic demand, Eu, $\left(10^{6} \mathrm{BTU} /\right.$

Household): Methane

Distillate

Electricity

44.9

44.9

29.2

41.4

41.6

25.0

36.5

35.4

22.4 
Residential Sector

Category: Mobile

End Use: Space Heat

\begin{tabular}{llllllllll} 
& 1972 & \multicolumn{4}{c}{1985} & & \multicolumn{2}{c}{2000} \\
\hline$f i$ & ei & $\mathrm{Di}$ & $\mathrm{fi}$ & $\mathrm{ei}$ & $\mathrm{Di}$ & $\mathrm{fi}$ & $\mathrm{ei}$ & $\mathrm{Di}$
\end{tabular}

Methane

Distillate .90

$\begin{array}{lll}6.2 & .90 \quad .59\end{array}$

17.9

.90

.60

23.3

Electricity

.101

$.3 \quad .10 \quad 1$

1.1 .10

1

1.5

Total fuel demand, D, $10^{12}$ BTU

6.5

19.0

24.8

Basis $10^{3}$ Households

61

209

296

saturation, s

1

Unit basic demand, Eu, $\left(10^{6} \mathrm{BTU} / \mathrm{house-}\right.$ hold): methane distillate

56.1

electricity

52.6

56.1

52.6

52.5

49.3 
Residential Sector

Category: SFD

End Use: Air Conditioning

fi $\quad$ i $D i \quad$ fi ei $\mathrm{Di}$ fi ei $\mathrm{Di}$

Methane

Distillate

Electricity Room

$0.18 \quad 1.82$

$0.02 \quad 1.99$

1.26

0.23

2.23

1.92

0.49

2.75

5.33

central

0.18

0.09

$2.44 \quad 0.84$

0.20

$3.01 \quad 1.93$

Total fuel demand, $D$, $10^{12} \mathrm{BTU}$

1.44

2.76

7.26

Basis $10^{3}$ households

2023

2472

3196

Saturation, s

0.2

0.32

0.69

Unit base demand, Eu Room:

(106 BTU/household) Central:

6.30

8.81

7.55

7.56

9.26

9.12 
Residential Sector

Category: SFA

End Use: Air Conditioning

\begin{tabular}{llllllllll} 
& 1972 & & & & 1985 & & & 2000 \\
\hline$f i$ & ei & Di & fi & ei & Di & fi & ei & Di \\
\hline
\end{tabular}

Methane.

Distillate

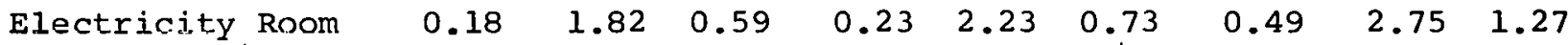

Central

\begin{tabular}{lllllll}
0.02 & 1.99 & 0.08 & 0.09 & 2.44 & 0.29 & 0.20 \\
\hline
\end{tabular}

$3.01 \quad 0.48$

Total fuel demand, $D$. $10^{12}$ BTU

0.67

1.02

1.75

Basis $10^{3}$ households

1,140

1158

1196

Saturation, S

0.2

0.32

0́.69

Unit basic demand, Eu Room

5.26

6.90

6.09

5.95

$\left(10^{6}\right.$

BTU/household) Central:

6.90

6.73

6. 03 


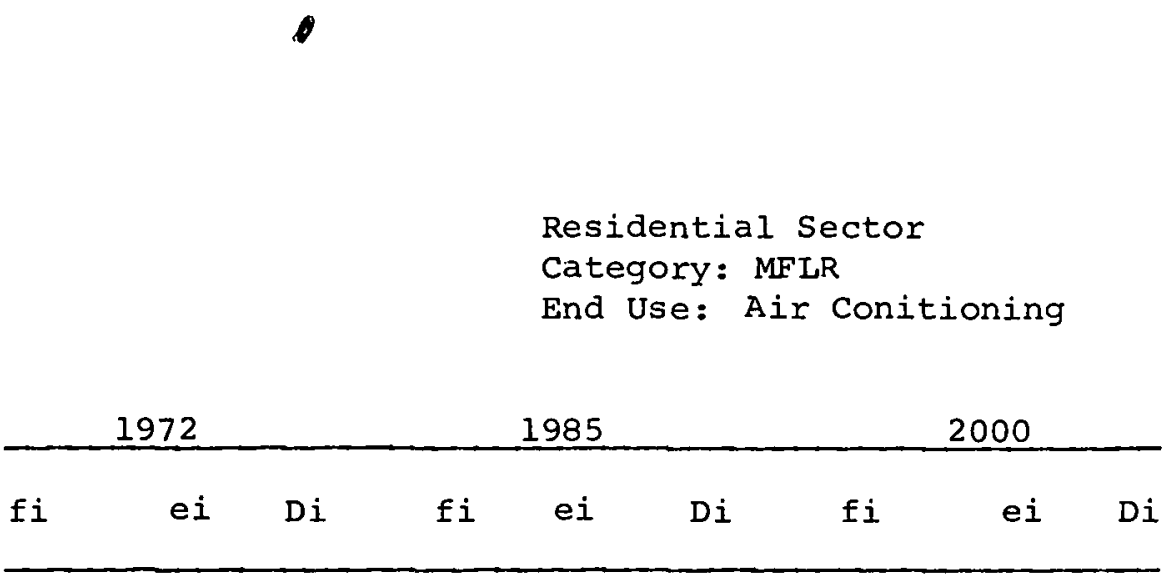

Methane

Distillate

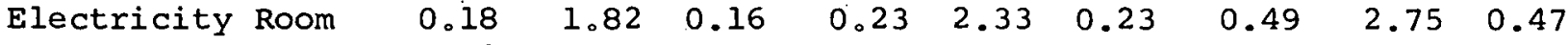

Central

$0.02 \quad 1.99$

0.02

0.09

2.44

0.09

0.20

$3.01 \quad 0.18$ Total fyel demand, D,
10 BTU

0.18

0.32

0.65

Basis $10^{3}$ households

368

469

575

Saturation, s

0.20

0.32

0.69

Unit basic demand, Eu. Room

(10 BTU/household) Central
4.39

5.74
4.92

5.38
4.63

4.80 


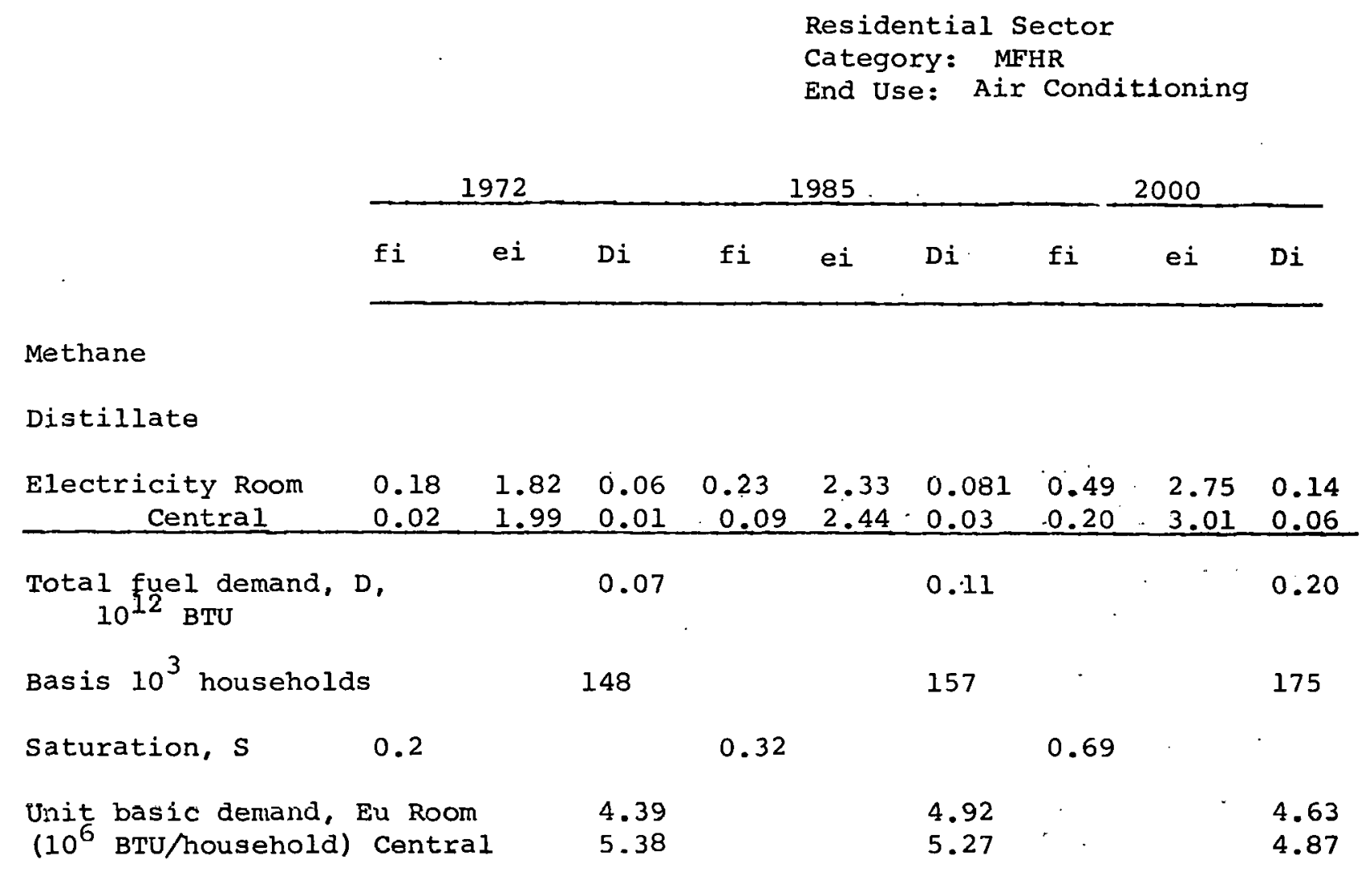




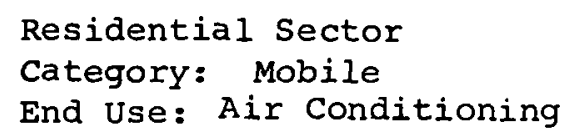

\begin{tabular}{lllllllll} 
& 1972 & & 1985 & & \multicolumn{2}{c}{2000} \\
\hline fi & ei & Di & fi & ei & Di & fi & ei & Di \\
\hline
\end{tabular}

Methane

Distillate

\begin{tabular}{|c|c|c|c|c|c|c|c|c|}
\hline Electricity & 1.82 & 0.04 & 0.32 & 2.33 & 0.16 & 0.69 & 2.75 & 0.39 \\
\hline $\begin{array}{l}\text { Total fuel demand, D, } \\
\qquad 0^{12} \text { BTU }\end{array}$ & & 0.04 & & & 0.16 & & & 0.39 \\
\hline Basis $10^{3}$ households & & 61 & & & 09 & & & 296 \\
\hline Saturation, S & & & 0.32 & & & 0.69 & & \\
\hline $\begin{array}{l}\text { Unit basic demand, Eu } \\
\left(10^{6} \text { BTU/household) }\right.\end{array}$ & & 5.64 & & & 5.64 & & & 5.29 \\
\hline
\end{tabular}




\section{Appendix 8}

Saturation Levels of Other Residential Energy Uses 
ANNUAL UNIT DEMAND AND SATURATION FOR

LIGHTING AND MISCELLANEOUS ELECTRIC APPLIANCES

IN NEW ENGLAND

\begin{tabular}{|c|c|c|c|c|c|c|}
\hline \multirow[t]{2}{*}{ END USE DEVICE } & \multicolumn{3}{|c|}{ SATURATION } & \multicolumn{3}{|c|}{ UNIT DEMAND $\left(10^{6}\right.$ Btu $)$} \\
\hline & $\underline{1972}$ & 1985 & 2000 & 1972 & 1985 & $\underline{2000}$ \\
\hline Lighting & 1.00 & 1.00 & 1.00 & 3.10 & 3.10 & 3.10 \\
\hline Dishwasher & 0.23 & 0.70 & 0.90 & 1.30 & 1.15 & 1.15 \\
\hline Washing Machine & 0.75 & 0.80 & 0.85 & 0.35 & 0.35 & 0.35 \\
\hline Dryer & 0.41 & 0.60 & 0.80 & 3.40 & 3.40 & 3.40 \\
\hline Color TV & 0.43 & 0.90 & 1.00 & 2.10 & 1.50 & 1.50 \\
\hline$B \& W T V$ & 0.82 & 0.80 & 0.70 & 1.20 & 0.40 & 0.40 \\
\hline Freezer & 0.19 & 0.35 & 0.50 & 4.80 & 4.50 & 4.20 \\
\hline Refrigerator & 1.00 & 1.10 & 1.25 & 4.50 & 4.50 & 4.50 \\
\hline Misc. Small Appliances & 0.60 & 0.70 & 0.85 & 2.50 & 2.50 & 2.50 \\
\hline Average & 0.60 & 0.73 & 0.88 & & & \\
\hline & SOURCE: & $\begin{array}{l}\text { U.S. } \\
\text { and L }\end{array}$ & $\begin{array}{r}\text { reau of } \\
(1976)\end{array}$ & Census & $(1972)$ & \\
\hline
\end{tabular}

Breakdown By Fuel Type For Cooling and Water Heating of Housing Units in New England in 1970

Fuel

Utility gas

Electricity

Liquid propane gas

Fuel oil

Coal

Wood

Other

None
Percentage of homes using a given fuel Cooking Waterheating

40.2

31.0

48.1

21.3

9.5

4.1

1.3

41.4

.1

.1

.3

.1

.1

.2

.4

1.7

Source: U.S. Bureau of Census (1972). 